Discussion Paper No. 11-024

Taxation, R\&D Tax Incentives and Patent Application in Europe

Christof Ernst and Christoph Spengel

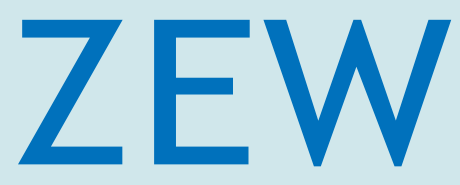

Zentrum für Europäische Wirtschaftsforschung $\mathrm{GmbH}$

Centre for European

Economic Research 
Discussion Paper No. 11-024

\title{
Taxation, R\&D Tax Incentives and Patent Application in Europe
}

\author{
Christof Ernst and Christoph Spengel
}

Download this ZEW Discussion Paper from our ftp server:

ftp://ftp.zew.de/pub/zew-docs/dp/dp11024.pdf

Die Discussion Papers dienen einer möglichst schnellen Verbreitung von neueren Forschungsarbeiten des ZEW. Die Beiträge liegen in alleiniger Verantwortung der Autoren und stellen nicht notwendigerweise die Meinung des ZEW dar.

Discussion Papers are intended to make results of ZEW research promptly available to other economists in order to encourage discussion and suggestions for revisions. The authors are solely responsible for the contents which do not necessarily represent the opinion of the ZEW. 


\section{Non-technical summary}

Innovation triggers positive effects on productivity and growth. It is therefore important to know whether taxation has an impact on research, development and innovation and whether taxation can be used as an instrument to foster research, development and innovation. Moreover, the generated intellectual assets can also increase the fiscal tax revenue. We add to the literature by analysing simultaneously effects from R\&D tax incentives and corporate income tax burden on R\&D investment and patenting behaviour of European corporations. We generate and use a panel of firm-specific patent applications at the European Patent Office (EPO) from 1998 to 2007.

We find positive effects of $R \& D$ tax incentives on the probability to invest in $R \& D$ in the R\&D phase. The marginal effect is an $11 \%$ increase of the odds ratio for a ten percentage point decrease of the B-Index equaling the introduction of a $10 \%$ tax credit on R\&D expenditures. $R \& D$ tax incentives seem to increase the tendency of rather small firms to start investing in R\&D.

We find a negative effect of the combined statutory corporate income tax rate on the number of patent applications. The marginal effect is estimated as an increase of the average count of applications by 0.09 for a decrease of the corporate income tax rate of ten percentage points. The effect in countries with $R \& D$ tax incentives is $156 \%$ larger indicating a stronger sensitivity to tax issues. The effect of the corporate income tax rate is $120 \%$ larger for inventions that were developed in cooperation with foreign inventors. Those cooperations seem to provide better opportunities for tax planning with IP ownership. Moreover, we find a marginal effect which is about $189 \%$ higher for firms with more than 5,000 employees. Larger firms have more options and more available locations in different countries to structure R\&D phase and IP phase tax-efficiently with regard to the overall tax burden.

A fiscal instrument to foster R\&D activity in the own country could be the use of R\&D tax incentives, which we found to have a positive effect on the probability to invest in R\&D, especially for smaller firms. Another option would be to lower the corporate income tax rate which we found to increase patent applications and, also, earlier R\&D investments in that specific country. 


\section{Das Wichtigste in Kürze}

Innovationen wirken sich positiv auf Produktivität und Wachstum aus. Daher ist es wichtig zu wissen, ob die Besteuerung der Unternehmen einen Einfluss auf Forschung, Entwicklung und Innovation der Unternehmen hat. Umgekehrt können generierte immaterielle Wirtschaftsgüter auch das Steueraufkommen erhöhen. Wir betrachten die Auswirkungen der steuerlichen Forschungsförderung auf die Phase der Investition in Forschung und Entwicklung (FuE) sowie die Auswirkungen der Besteuerung der Erträge auf die Phase der Generierung von immateriellen Wirtschaftsgütern (insbesondere Patente) in einer Gesamtanalyse. Für die Analyse haben wir ein Modell definiert, bei dem Unternehmen die Verteilung von Forschungs- und Entwicklungsaufgaben sowie von immateriellen Wirtschaftsgütern im Konzern mit Blick auf die resultierende Gesamtsteuerbelastung optimieren.Wir haben dazu einen Datensatz individualisierter Patentanmeldungen europäischer Kapitalgesellschaften beim Europäischen Patentamt erstellt und für die Jahre 1998 bis 2007 analysiert.

Wir finden in der Analyse positive Auswirkungen von Steueranreizen für FuE-Inputs auf die Wahrscheinlichkeit, dass wir eine Investition vor allem kleinerer Unternehmen in FuE beobachten. Das sogenannte Chancenverhältnis, dass ein Unternehmen in FuE investiert und ein Patent anmeldet, wird um 11\% erhöht, wenn sich der sogenannte B-Index um 10 Prozentpunkte vermindert. Eine solche Reduktion des B-Index ließe sich in etwa durch die Einführung einer Steuergutschrift von 10\% für FuE-Ausgaben erzielen.

Wir finden zudem negative Auswirkungen des kombinierten tariflichen Ertragsteuersatzes für Kapitalgesellschaften auf die Anzahl der Patentanmeldungen. Demnach erhöht sich die durchschnittliche Anzahl der Patentanmeldungen um 0,09 wenn der Steuersatz um 10 Prozentpunkte fällt. Diese Reaktion auf die Steuerbelastung lässt sich durch steueroptimierte Ansiedlung von Forschungsaktivitäten und immateriellen Wirtschaftsgütern zwischen potentiellen Standorten, aber auch durch steueroptimierte Aufgabenverteilung und Strukturierung von Forschungsaufträgen im Konzern erklären. Zudem reagieren Unternehmen in Ländern mit Steueranreizen für FuE um 156\% stärker auf die Veränderung des Steuersatzes als das Gesamtsample. Wir beobachten auch einen um 120\% stärkeren Effekt bei Forschungskooperationen über die Landesgrenzen hinweg. Die Reaktion auf den Steuersatz ist zudem bei großen Unternehmen mit mehr als 5.000 Arbeitnehmern um 189\% stärker ausgeprägt.

Steueranreize für FuE-Inputs könnten demnach ein Instrument sein, den Einstieg kleinerer Unternehmen in FuE zu befördern und den Ort der physischen FuE-Kompetenz im Inland zu halten. Außerdem wirkt sich die Senkung des Steuersatzes positiv auf die Generierung und Verlagerung immaterieller Wirtschaftsgüter ins Inland aus, indirekt ist damit auch eine Erhöhung der FuE-Tätigkeit im Inland zu erwarten. 


\title{
Taxation, R\&D Tax Incentives and Patent Application in Europe
}

\section{Christof Ernstab Christoph Spengel}

\begin{abstract}
The focus of this paper is on effects from tax incentives for research and development inputs (R\&D) and corporate income tax on business $R \& D$ and patenting behaviour. First, we provide a theoretical discussion of tax planning with $R \& D$ and intellectual property (IP) ownership. Further, we employ firm-specific micro-data on patent applications of European corporations at the European Patent Office to test reactions on changes in R\&D tax incentives and corporate tax burden. We find a positive impact of R\&D tax incentives and a negative impact of the statutory corporate income tax rate on patenting. R\&D incentives rather influence the tendency to invest in $\mathrm{R} \& \mathrm{D}$, whereas the tax burden rather influences the scale of R\&D investment and the count of patent applications.
\end{abstract}

Keywords: Patent, R\&D, Tax Incentives, Taxation, EU

JEL-Codes: H25, H26, O30

Aknowledgement: The paper has benefitted substantially from comments by Sarah Borgloh, Christina Elschner, Clemens Fuest, Alexander Kalb, Nadine Riedel and participants of the congress of the IIPF in Uppsala, of the workshop „Empirische Forschung in der Betriebswirtschaftlichen Steuerlehre" in Mannheim and the "SEEK Conference" in Mannheim. Research support from the research programme "Strengthening Efficiency and Competitiveness in the European Knowledge Economies (SEEK)", financed by the state government of Baden-Württemberg, is gratefully acknowledged. All remaining errors are in the responsibility of the authors.

a Zentrum für Europäische Wirtschaftsforschung (ZEW) Mannheim.

b Corresponding author: Christof Ernst, email: ernst@zew.de, phone: +49 621 1235-191.

c University of Mannheim and Zentrum für Europäische Wirtschaftsforschung (ZEW) Mannheim. 


\section{Introduction}

Innovation triggers positive effects on productivity and growth. It is important to know whether taxation has an impact on research, development and innovation and whether taxation can be used as an instrument to foster research, development and innovation. Within the past two decades, many OECD member states have introduced or modified specific tax incentives to increase the business expenditures for research and development. Expenditures for research and development (R\&D) generate a tax shield which reduces the firms' tax base. Yet, taxation also reduces the yield from innovation. We add to the literature by analysing simultaneously effects from R\&D tax incentives and corporate income tax burden on patenting behaviour. We generate and use a panel of firm-specific patent applications at the European Patent Office (EPO) from 1998 to 2007. Patent data from European countries were rarely used before in empirical tax-research. We also provide a year-specific measure of R\&D tax incentives for a majority of the EU countries plus Norway. ${ }^{1}$ Our data is thus an innovative data set with micro-level data that captures up-to-date information and rarely used European data. Our contribution to the literature is a simultaneous analysis of the impact of R\&D tax incentives and the corporate tax on R\&D activity and on patenting. Our results show that firms' patenting activity reacts positively to $R \& D$ tax incentives as they increase the propensity to invest in $R \& D$ and to patent. We also find that firms in countries with $R \& D$ incentives react more sensitive to taxation. Moreover, a higher corporate income tax rate decreases the count of patent applications. We find that larger firms are more responsive to the combined corporate income tax rate than smaller ones. The same holds true for cross-border R\&D cooperation which is found to be more responsive to the combined corporate income tax rate. Fiscal policy is found to interact with innovation policy offering opportunities to foster R\&D and innovation in Europe.

The literature on innovation shows that R\&D activity is influenced by many factors. For multinational groups, the respective technological strengths and weaknesses of the group and of the potential host country matter (Kuemmerle (1997); Le Bas and Sierra (2002)). The size of the market is important when products should be adapted to the specific market (Mansfield et al. (1979); Patel and Vega (1999)). The supply of R\&D staff and high-quality infrastructure are important location factors (Cantwell and Piscitello (2005)). The typical activities of the specific group-members are decisive for the acquisition of R\&D assignments (Guimón (2009)). A typical pathway in the globalisation of R\&D leads from production and technical assignments to R\&D (Lall (1979); Defever (2006): 675 f.). Studies also reveal a positive ef-

1 We use the so called B-Index as underlying methodology. The B-Index is a measure for the fiscal generosity of a tax system towards $R \& D$ investment and equals the tax component of $R \& D$ user costs. Lower values of the B-Index indicate higher incentives from the tax system for investments in R\&D capital. A detailed illustration of the B-Index can be found in 1.1.1. The index can be interpreted as the tax component of the user costs of R\&D. 
fect of cost-savings which includes beneficial tax treatment (Patel and Vega (1999): 146-147; Kumar (2001): 171; Edler et al. (2003): 86; Hollenstein (2008): 11 f.). ${ }^{2}$

A large strand of literature analyses the effects of $R \& D$ tax incentives on business $R \& D$ activity and finds substantial evidence that they have a positive effect. Hall and van Reenen (2000) as well as Bloom et al. (2002) estimate an elasticity for R\&D performed of approximatelly -1 regarding the so called user cost of R\&D capital, although Hall and van Reenen find strong variation in their survey. ${ }^{3}$ Parsons and Phillips (2007) present an elasticity of -1.2 (on average) in the long run comparing seventeen different studies. A small part of that literature focuses on the influence of $R \& D$ tax incentives on the relocation of $R \& D$ across borders. Billings (2003) finds a higher average growth rate of R\&D performed in foreign affiliates of US multinationals in countries offering tax incentives. Bloom and Griffith (2001) find that $R \& D$ in one country responds positively to decreases of the user cost of R\&D in foreign countries, which they explain by "footloose" R\&D that was shifted to foreign locations. Hall and van Reenen (2000) raise the question of "footloose" R\&D in their study as well. These studies provide evidence that tax incentives can reward the relocation of R\&D activity.

Another small strand of literature investigates the effects of the corporate tax burden on the location of patents and intellectual property. Mutti and Grubert (2008) find indirect evidence that high royalty revenues in US companies are more often obtained in foreign low-tax subsidiaries. Karkinsky and Riedel (2009) find a decrease of $-2.9 \%$ on the number of patent applications at the European Patent Office (EPO) for a one percentage point increase of the corporate income tax rate between 1995 and 2003. Dischinger and Riedel (2010) find a decreasing volume of intangible assets with increasing tax burden in subsidiaries of multinational groups. They find that a decrease in the average tax difference to other affiliates by 1 percentage point raises the subsidiary's level of intangible assets by $1.6 \%$. These studies provide evidence that a higher tax rate can decrease patenting activity.

The paper is structured as follows: We first provide a discussion of the parameters for taxation and tax planning with R\&D and intellectual property (IP) ownership. Second, we describe the data used. Third, we conduct an empirical analysis including several sensitivity analyses. Forth, we conclude.

\section{$1 \quad$ R\&D and Patenting and Interaction with Taxation}

We analyse tax treatment and tax planning with inputs in and outputs from R\&D activity. On the output side, we especially focus on patents. Patents are an important sort of intellectual assets in multinational firms and are often used as indicator for innovative activity, for exam-

\footnotetext{
2 Others: Hines (1994); Yang and Jiang (2007): 352; Atkinson (2007): 621.

3 The elasticity is defined as $1 \%$ change of the dependent variable for a $1 \%$ change of the independent variable. User costs of R\&D can be defined as costs that arise for a firm to borrow and use a unit of R\&D capital for one period. The lower these user cost are the higher should be the amount of private R\&D investment. See in detail in1.1.1.
} 
ple in Acs et al. (2002), Cantwell and Piscitello (2005), Le Bas and Sierra (2002), Harhoff and Thoma (2009)). Also, R\&D and patenting can be regarded as closely related to each other, as many empirical results show: Griliches (1990); Hall et al. (1986) and Bosch et al. (2005) find a strong relationship between patents and $R \& D$. We thus take patent applications as measure for the output from R\&D inputs. We furthermore employ the link between R\&D activity and patenting to use patent applications as a proxy for the scale of $R \& D$ inputs in our analysis in chapter 3 . We do this, as it is not possible to observe the necessary firm-specific R\&D expenditures directly. The proxy seems to be reasonable as we find that the country of the inventor, as a proxy for the place of R\&D activity, and the country of the patent applicant are equal for $92 \%$ of the applications in our sample and we indeed observe the location of R\&D activity in most cases by observing the location of the patent applicant.

We use the patent applicants rather than the patent inventors - which are both recorded in an application. The patent applicant is the legal owner of the patent at the time of application because only the legal owner of the underlying invention is entitled to apply for a patent. We find it convincing to focus on the patent applicant because the legal owner of a patent is also the relevant subject for taxation (Quick and Day (2006)). Doing so, we trace patents which result from the applicant's own R\&D activity, his joint R\&D activity together with others or R\&D activity the applicant has contracted out. ${ }^{4}$

\subsection{Taxation}

In the following, we describe the most important tax parameters and channels of interaction between taxation, R\&D activity and intellectual property (IP) ownership. We also briefly discuss possible ways how the legal owner could react to the tax burden, how he could do tax planning and how we observe it in our data.

Figure 1: Interaction with taxation in the R\&D-phase and in the IP-phase.

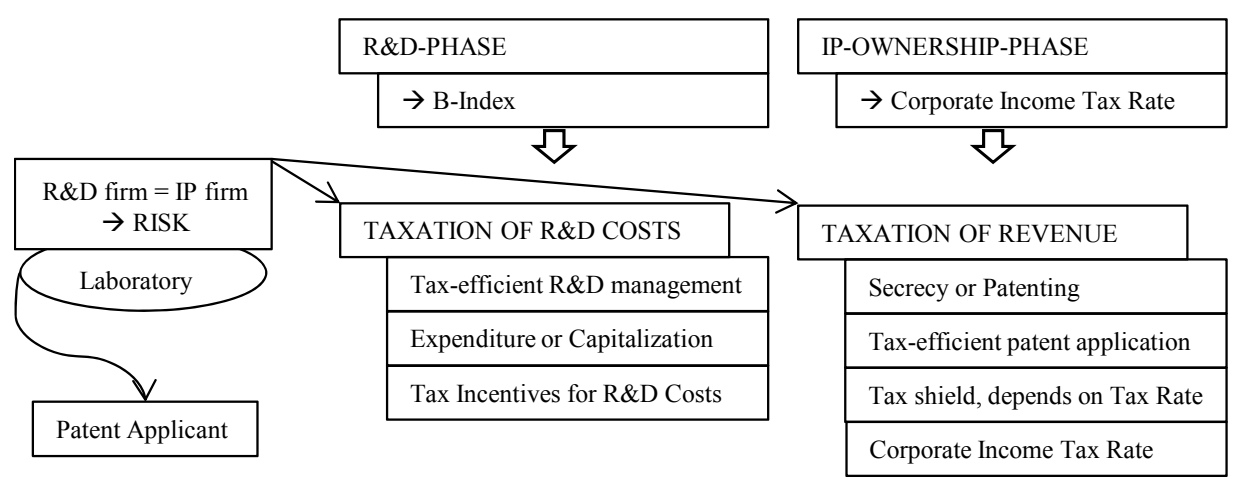

Source: Own illustration.

4 We do not trace subsequent trading or licensing after the patent application, because it is not possible with the data available to us. We rather focus on the initial distribution and localisation of patent applicants, which we expect to be determined - besides other factors - by R\&D tax incentives and the tax rate. 
Regarding the time structure, we divide the patent-generating process into two stages: First, the period when $R \& D$ is undertaken and tax deductible $R \& D$ costs occur ( $R \& D$ phase); Second, the period when the patent application is filed and the IP generates income (IP ownership phase). A rational management that maximizes the firm's value should do tax planning to keep the firm's costs and tax burden low. Costs include the tax burden for the R\&D investment project (R\&D phase) and the generated intellectual assets (IP phase). Figure 1 displays the following considerations in a structured graph.

\subsubsection{Tax Incentives in the R\&D Phase}

The management of a firm that optimises the firm's value will invest in R\&D capital until the marginal product from R\&D capital multiplied by the market price of R\&D capital equals the user cost for R\&D capital ${ }^{5}$ :

$$
\frac{\partial F_{t+1}\left(K_{t}, X_{t+1}\right)}{\partial K_{t}} * P_{t+1}=C_{t+1}
$$

$P_{t+1}$ equals the market price of a unit of produced output from R\&D. The derivation of the production function $F$ with respect to the stock of R\&D capital $K$ indicates the marginal product from R\&D capital. Finally, $C_{t+1}$ is defined as the user cost of R\&D capital. In other words, the firm will invest in $R \& D$ capital until the last (marginal) $R \& D$ project yields a return equal to the user cost of R\&D. The user cost of $R \& D$ is $C=P_{R \& D} *\left(\frac{1-Z^{*} t}{1-t}\right) *(\rho+\delta-\pi)$.

$\rho$ is the firm-specific rate of return which must be earned to pay the shareholders; $\delta$ is the economic depreciation of the R\&D capital stock and $\pi$ is the rate of inflation reducing the price of a unit of R\&D in the next period. $P_{R \& D}$ denotes the market price of a unit of R\&D capital, for example the hourly wage for an engineer. A firm renting one unit of R\&D capital for one year must earn at least the market price for that unit plus it's depreciation plus the required return for the shareholders. The amount is lessened by the inflation on the price for R\&D. A firm should invest in projects with a larger return and it should stop projects having a return below the user costs of R\&D. If we set $P_{R \& D}$ to one and $\pi$ to zero, we can simplify the user costs of $R \& D$ capital to: $C=\left(\frac{1-Z^{*} t}{1-t}\right) *(\rho+\delta)$. We can now decompose the user cost in a "tax" component $\left(\frac{1-Z^{*} t}{1-t}\right)$, which is equal to the B-Index, and an "economic" component $(\rho+\delta)$ (Guellec and van Pottelsberghe de la Potterie (2003): 229). Bloom et al. (2002) find that the tax component rather than the economic component of user costs R\&D has an influence on business R\&D. We, thus, choose the B-Index instead of the full user cost. The poten-

5 The following derivation of user costs for R\&D on this page is taken from the report of the Expert Group on R\&D Tax Incentives Evaluation (2008). 
tial number of R\&D projects should increase for a decreasing B-Index (Warda (2001)) as the index is a multiplier in the formula of the user cost of $R \& D$ which raises or lowers them.

The B-Index equals $\left(\frac{1-Z^{*} t}{1-t}\right)$. The numerator represents the net present value of an investment in a unit of $R \& D$ after having considered the tax shield and possible tax credits for R\&D expenditures. The firm which invests a monetary unit in R\&D must first earn the gross amount at the market and is taxed on its return with the combined statutory corporate income tax rate $t$. Therefore, $\left(1-Z^{*} t\right)$ must be divided by $(1-t)$ to arrive at the so called net tax price of $R \& D$ capital from retained earnings. $Z$ is the present value of tax depreciation, tax allowances and tax credits for $R \& D$ expenditures and equals one if all $R \& D$ expenditures are immediately deductible from the taxable base ( $B$ then equals one and taxation has no influence on the R\&D user costs). See Table A-2 for more details on the calculation of $Z$.

We use the B-Index in our analysis as measure for the available R\&D tax incentives in a jurisdiction. Tax credits for R\&D expenditures in 2007 were granted in Austria, France, Ireland, Italy, the Netherlands, Portugal and Spain. They differ according to whether they can be applied on the whole R\&D expenditures (volume-based) or only on the increase in expenditures (incremental). Belgium, the Czech Republic, Hungary, Malta, Poland, Slovenia and the United Kingdom apply tax incentives in the form of extra-deductions from the taxable base which exceed the actual expenditures. Belgium and Poland grant the incentive for investments in fixed assets only. R\&D capital expenditures, such as R\&D equipment like laboratory machinery, microscopes, must be capitalised and are in most cases subject to depreciation like non-R\&D assets, except that there is accelerated depreciation. Belgium, Greece and the United Kingdom grant accelerated depreciation for certain investments in fixed assets used for R\&D. Belgium and the Netherlands apply a special form of R\&D tax incentive by cutting costs for $R \& D$ personnel from the payable wage tax. ${ }^{6}$ Figure 2 displays the development of the B-Index for large firms in selected countries. The underlying parameters can be found in Table A-3.7 Spain and Portugal, followed by Hungary, display low values for the B-Index in the whole period. Countries like the Czech Republic, France, Italy and Malta display higher values with strong decreases of the B-Index in 2004 and 2005. The United Kingdom displays a strong decrease in 2002 indicating the introduction of the extra allowance for R\&D costs. Austria, Belgium and the Netherlands kept almost constant values over time.

\footnotetext{
6 Wage tax is withheld from employees wage payments but paid net of R\&D subsidy to the fiscal authorities, thus resulting in a tax benefit for the employing firm.

7 Refunding, carry back and carry forward of unused tax credits can't be taken into account. It is assumed that $\mathrm{R} \& \mathrm{D}$ is fully eligible for the credit and does not exceed limits. We assume $60 \%$ of R\&D expenditures for labour, $30 \%$ for other current expenditures and $10 \%$ for capital expenditures. The employed discount rate is $10 \%$. We focus on R\&D subsidies eligible for R\&D in the private sector. Hence, specific and usually more beneficial incentives for supporting public R\&D, as it was the case for example in Denmark, are not in our calculation. R\&D with public institutions only accounts for a few percent of the overall R\&D expenditures. For example, in 2007 the share was $4.1 \%$ in Germany, see Stifterverband für die Deutsche Wissenschaft (2009): $30 \mathrm{f}$.
} 
Figure 2: Development of the B-Index on R\&D costs in selected countries.

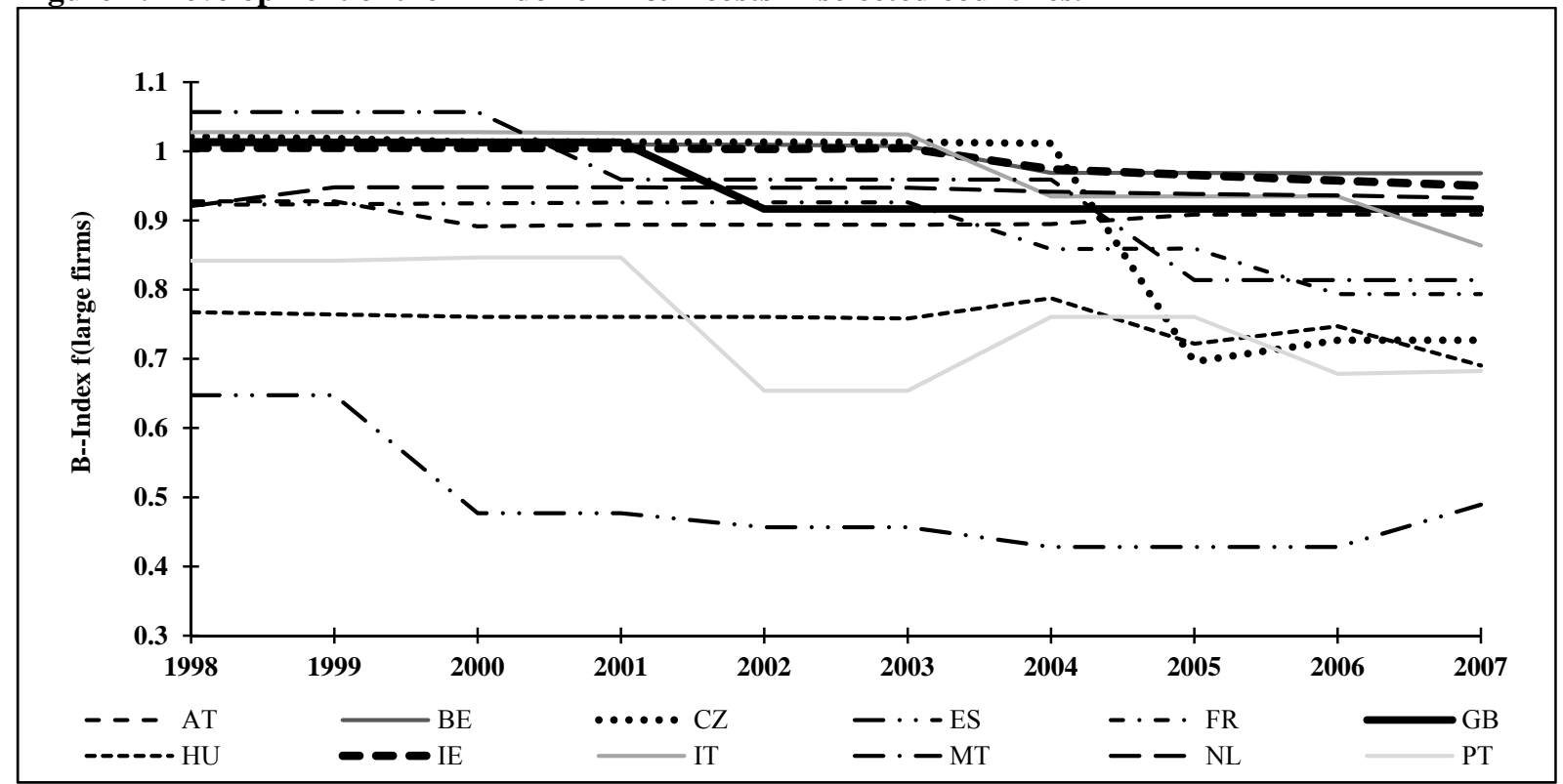

Note: The graphic displays the development of the B-Index for large firms from 1998 to 2007. Lower values indicate a more attractive tax environment for business R\&D and vice versa. Source: Own calculations.

However, there is an obvious trend towards lower values for the B-Index. ${ }^{8}$ Tax planning with $R \& D$ tax incentives includes deferral of $\mathrm{R} \& \mathrm{D}$ expenditures or acceleration of $\mathrm{R} \& \mathrm{D}$ projects by managing $R \& D$ projects in a tax-efficient manner. Decelerating a project could be useful when the government for example announces the introduction of an incentive in the following fiscal year.

Capitalization of $R \& D$ costs: The immediate deduction of the $R \& D$ costs reduces taxable income and thus tax payments. R\&D costs usually consist of revenue expenditures (for example for R\&D staff) and capital expenditures (for example R\&D equipment). The question arises whether $R \& D$ revenue expenditures need to be capitalised as an asset in its own right when they represent an independent economic value. ${ }^{9}$ If deducted, they become taxeffective in the same year. If capitalized, they lower the taxable income of the current and the following period by way of depreciation and it takes longer until they become fully taxeffective. Capitalisation usually results in a disadvantageous interest effect and mandatory capitalisation, thus, represents an economic disadvantage for profitable firms and increases the B-Index.

8 Tax incentives based on IP ownership emerged only recently or were expanded in recent years, like in Belgium in 2008, the Netherlands in 2007 and Spain in 2008 (France and Ireland extended their low tax regime in 2008). Therefore, they are not considered in this study. See e.g. Eynatten (2008); Eynatten and Brauns (2010); Taieb (2008); Nárdiz (19).

9 Greece, Norway, Poland and Slovakia require mandatory capitalisation either of research or development costs or both as far as the R\&D project fulfills certain objectivity requirements. Within these countries, the value of such capitalised R\&D expenditures is usually depreciated over 5 years. The other countries either treat $R \& D$ costs as expenses or capitalisation is optional (Verlinden and Smits (2009); IBFD (2009a); Endres et al. (2007); OECD (2009)). Additional sources for financial accounting are Hoogendoorn (1996); Liangqi (1994); Swanson and Singer (2002); Jacobs (2007). 


\subsubsection{Taxation in the IP Ownership Phase}

$R \& D$ activities generate $R \& D$ costs that are deductible from the firm's income tax base. They create a valuable tax shield equaling the net present value of deductible costs multiplied by the tax rate. The value of the tax shield thus increases with the tax rate given the availability of profits to balance the costs and to avoid losses. The profitability of R\&D investments plays an important role as the taxation of profits and the treatment of deductions or losses, such as loss carry-back, carry-forward or taxation with group-relief, may generate contrary incentives for tax planning. R\&D is risky (Harhoff et al. (1999)), but studies show that the private yield on business R\&D on average is positive and even higher than the yield to physical capital (Sougiannis (1994); Hall and Oriani (2006); Hall et al. (2010)). Moreover, a potential patent applicant at the EPO has to bear high costs (roughly €5K) to push an application. An EPO application observed by us thus reflects particularly successful R\&D activity. Our further analysis accordingly focuses on profitable R\&D-projects.

Taxation of return from generated IP: Corresponding to the deductibility of expenditures, the return from $R \& D$ activities is subject to tax irrespective of the kind of return. The return might be directly from increased turnover or indirectly via licensing or selling a patent. Under the general taxation principles, these results are subject to the income tax of the legal owner, which is presumably the patent applicant that we observe. It is mainly the domestic tax rate that matters in this respect because a major part of the taxable profits will arise from domestic sources. ${ }^{10}$ However, if profits stem from sources in foreign countries, these foreign countries may have, depending on the kind of transaction and the underlying structure, a right to tax these profits. Allmost all countries in our study have agreed on treaties among each other to avoid double taxation. Those treaties entitle the country of the recipient of royalties to tax the profits and they limit withholding tax rates in the foreign country to $12 \%$ and below. ${ }^{11}$ The directive on a common system of taxation applicable to interest and royalty payments of the Council of the European Union (2003/49/EG) also set the withholding tax rates to zero for royalty payments among members of multinational groups within the common market in the EU since 2004. ${ }^{12}$ The domestic tax rates are above both levels and determine the effective tax burden. We can thus focus on the domestic tax rate. ${ }^{13}$ Tax-efficient behaviour could defer taxation to a later point by shifting the filing date of the application or by relying on secrecy instead of patenting. Know-how is more difficult to observe and to evaluate for fiscal authorities

\footnotetext{
10 Just $35 \%$ of a sample of European companies declared that they license out patents to other companies. $28 \%$ of those companies licensed out more than $40 \%$ of their patents to partners in foreign countries, see Zuniqa and Guellec (2009): 14.

11 These rates apply for royalties for industrial know-how and patents. Exceptions are Greece, Ireland, Slovakia and Portugal, which have no treaty in a few cases.

12 However, transitional periods apply for the Czech Republic, Greece, Spain, Poland and Portugal.

13 The only exception is Slovenia, where we found an exemption for foreign royalty income from 1998 to 2001 , which lowers the effective tax burden to the foreign withholding tax rate.
} 
than a patent and offers more options to shape the tax burden. A granted patent immediately attracts taxable income as it becomes manifest as an asset and the subsequent user in the production chain has to finance the return form the IP. The use of know-how in a unit or within a group is to a larger extent informal and can defer tax payment as the return on the IP is then financed by the consumer at the end of the value chain when he pays an increased price for the purchased product.

\subsubsection{Group Structures}

The net principle for taxation implies that a firm is entitled to deduct its costs for R\&D given that the R\&D activity supports the firm's business. Thus, among the associated entities of a multinational group, the entity which economically backs risks and costs and is the beneficiary of the results, is entitled to use the tax shield from the costs. A main target of tax planning is the use of differences in the international levels of taxation by allocating costs to firms in high tax locations and earnings to low tax locations. Yet, R\&D and resulting IP must be analysed and optimized together as it is not straightforward to separate them for tax purposes.

A multinational group with firms in high-tax and low-tax locations can choose a licensing model where an especially dedicated IP-firm conducts R\&D, acquires ownership of the results and licenses the IP to other entities (Norton and Burns (2006)). The IP-firm bears costs and risks and allocates the costs subsequently to firms that use the IP by charging royalties. The IP-firm as licensor can use available domestic R\&D tax incentives for its underlying intramural R\&D activity. The IP-firm and the licensees can also try to use their differing statutory income tax rates to shape the allocation of taxable profits (Adams and Godshaw (2002)). However, the payments for taxation must be determined according to the arm's length principle (Marti and Ledergerber (2005): 188), which in principle equals the "market price" among unassociated parties (Fletcher and Cawdron (2006)). ${ }^{14}$ Tax authorities also challenge the deduction of royalties as hidden distribution of profits if a firm pays for patents it does not use (Eynatten (2008): 504). If, on the other hand, the firm uses patents without paying, tax authorities might challenge it as constructive equity contribution. The result will be corrections if the payments deviate from reasonable prices. There is growing attention of tax authorities for transfer pricing (Ernst\&Young (2008): 5; Henshall (2010)). The central IP-firm should therefore reside in a low-tax country with a generous R\&D tax incentive to be taxefficient as the scope for shifting profits and costs with transfer pricing is rather limited.

\footnotetext{
14 The determination of the "market value" raises serious problems (Vögele et al. (2004): chapter P, note 247). Intangibles are used in different markets and in different enterprises and it is often hardly possible to find a comparable transaction between unassociated parties. The most important methods to measure the applicable price are the Comparable Uncontrolled Transaction Method (OECD (2009), chapter II, 2.6-2.13), the Residual Profit Split (OECD (2009), chapter II, 3.5-3.25) and some nationally accepted rules of thumb (Adams and Godshaw (2002); Marti and Ledergerber (2005): 190; Verlinden and Smits (2009): 86 f., 97 f.).
} 
Figure 3 displays a contract $R \& D$-structure across border (Vögele et al. (2004): chapter $\mathrm{P}$, note 58 ). Contract $\mathrm{R} \& \mathrm{D}$ is an option to divide the place of $\mathrm{R} \& \mathrm{D}$ activity and the place of IP-ownership which is recognized for tax purposes if the IP-firm as a principal effectively directs the undertaken $R \& D$ of the contractor (R\&D firm) and provides the know-how. It

Figure 3: Structure of cross-border contract $R \& D$ and purchase of a patent.

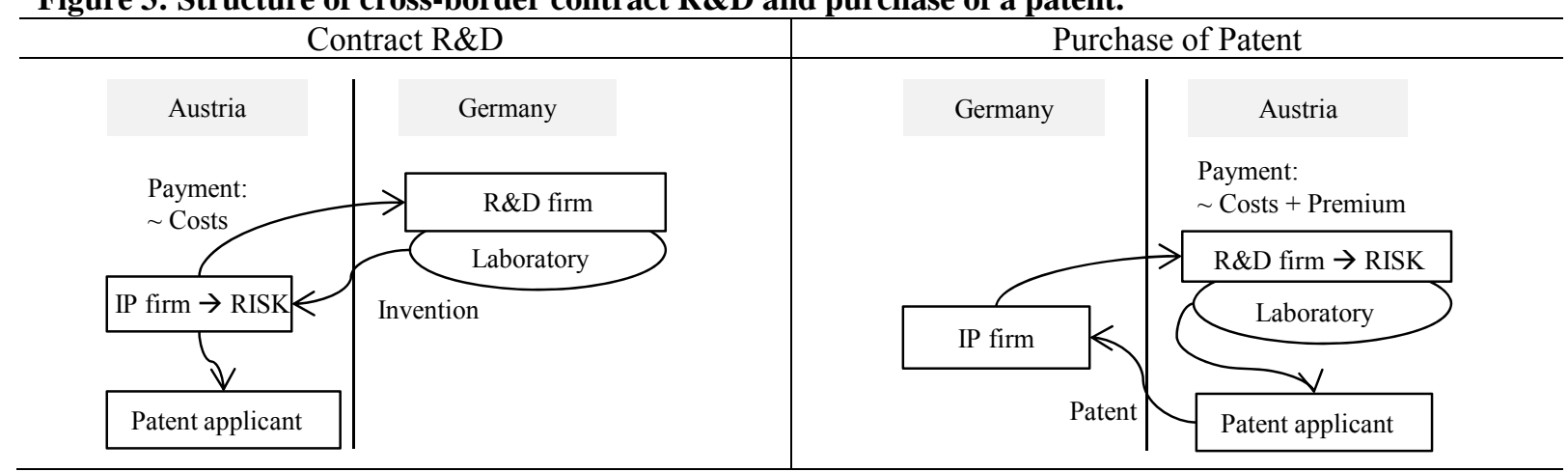

Source: Own illustration.

must also effectively bear the risks (Henshall (2010)). The principal's accounting for contract $R \& D$ is similar to the accounting for intramural R\&D: The principal acquires the ownership and the tax shield from costs for contract $R \& D$ and would be observable as patent applicant. ${ }^{15}$ The payment from the principal to the contractor according to arm's length includes the costs plus a rather low premium ${ }^{16}$ as the contractor bears no risk. Most of the taxable return from $R \& D$ in this model arises therefore in the country of the principal and not in the country of the contractor. This makes the tax rate of the IP-firm the most important factor. Contract R\&D is, thus, effective for allocating IP in a low tax location while keeping R\&D activity physically at a high tax location. The principal can also profit from $R \& D$ tax incentives in many countries. ${ }^{17}$ Groups can use the domestic R\&D tax incentives by replacing former intramural R\&D with contract $R \& D$ in foreign countries. ${ }^{18}$ Intramural R\&D, formerly done in the German R\&D-firm, could be replaced with contract R\&D from a new Austrian IP-firm to the German R\&D-firm. IP and patents would then accrue within the Austrian IP-firm and the group could, as a result, use the tax credit of $8 \%$ in Austria and reduce the tax rate on profits from IP from $39.35 \%$ in Germany to $25 \%$ in Austria.

A purchase of ready-made IP is given if the IP was created by a supplier (R\&D-firm) and sold to an acquirer (IP-firm). The supplier backs the risk, provides the know-how, manages the work and acquires transitional ownership and, thus, becomes observable as patent ap-

15 The principal backs the risk of unsuccessful R\&D (OECD (2009): chapter VII, note 7.41). Capitalisation of the costs, thus, depends on comparable rules as for own intramural R\&D.

16 OECD (2009), chapter VII, note 7.41; Debatin et al. (2009): MA Art. 9, note 335.

17 Those countries are: Austria, Spain, France, Greece, Hungary, Italy, Portugal and the United Kingdom.

18 This opportunity for tax planning originates from the freedom of establishment and services (Art. 43 and Art. 49 EC Treaty) in jurisdictions that provide tax subsidies for contract R\&D and was confirmed by decision of the European Court of Justice (see e.g. ECJ, 10. 3. 2005 - C-39/04, Laboratoires Fournier SA/Direction des vérifications nationales et internationales); Schuch and Wehinger (2005); Scheunemann and Dennisen (2010)). 
plicant. R\&D costs are eligible for R\&D tax incentives in the country of the R\&D-firm as the supplier. Selling the patent implies that the underlying legal title is transferred by way of assignation (Vögele et al. (2004), chapter P, note 251). Arm's length considerations apply among affiliated entities, and, as the supplier backs the risks, he obtains a payment including its costs plus a high premium. The high premium is subject to tax in the country of the supplier which makes the tax rate of the supplier the most important parameter. Structuring R\&D and IP-ownership by using intra-group purchasing of IP provides a way to locate R\&D and IP initialy in a country with generous R\&D tax incentives and a low tax rate.

Shifting IP to foreign tax locations to obtain a lower tax burden is generally possible. Yet, it is too late to shift for tax-purposes if IP already generates income or is otherwise visible for tax authorities. The gains from transferring the assets and possible hidden reserves are taxable in the country of origin and they can trigger adverse tax effects that make the shifting of IP useless (Frick and Kronauer (2005)). The transferred assets will be subject to tax at the "market value" of the asset less its residual book value in tax accounting (Figure 4). ${ }^{19}$

Figure 4: Tax effects for cross-border shifting of IP.

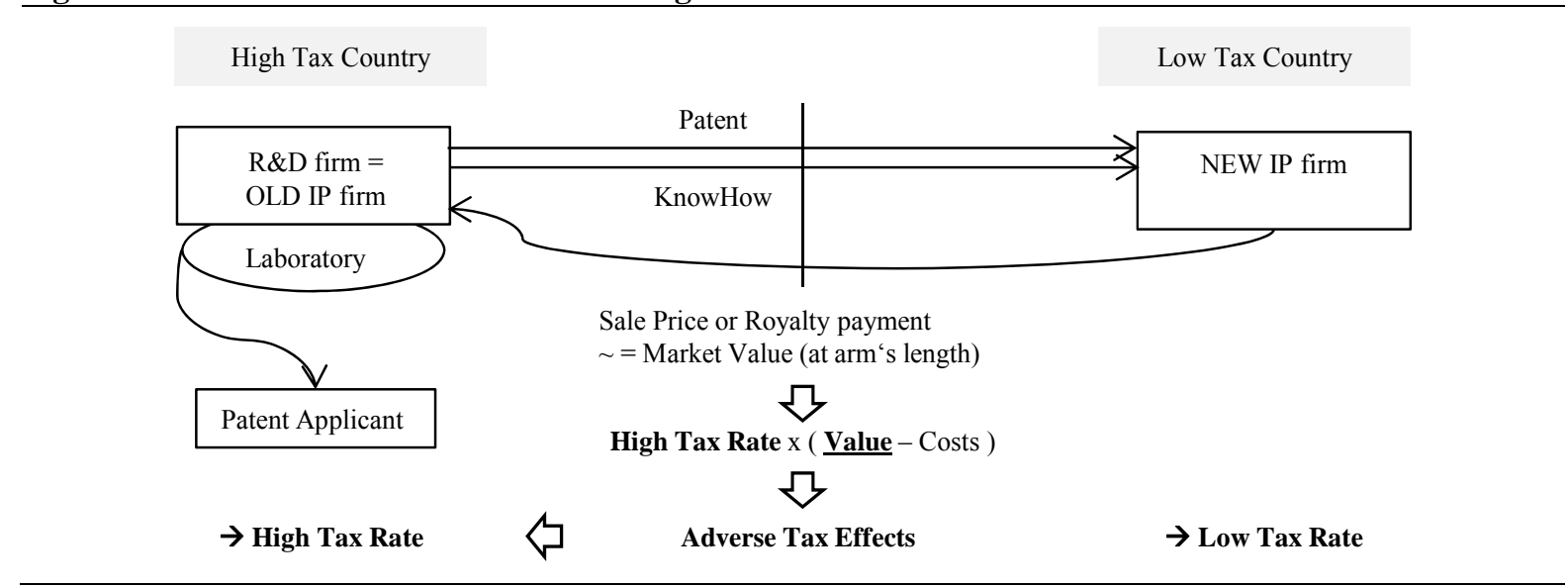

Source: Own illustration.

A tax-efficient strategy could be to shift IP before a taxable value becomes obvious (Meeker (2003)). However, fiscal authorities are aware of such transfers and there is a high risk that the transaction will be uncovered and corrected. Therefore, tax-efficient structuring of the R\&D phase and the IP ownership phase in a group should be done beforehand as it is costly after the assignment of R\&D tasks.

To sum up, the initial patent applicant in a tax-efficient structure would reside in all three models in a low tax location with also generous R\&D tax incentives. Shifting IP across

\footnotetext{
19 There are further models to structure IP ownership tax-efficiently. One example are cost-sharing agreements that enable several firms to cooperate in R\&D projects and to share costs and results from IP equally among the them. However, we found only very few obvious cases of cost-sharing in our data. Other models include the use of foreign permanent establishments to locate IP and to shift IP across borders. It also seems to be possible to use the tax-efficient transaction of shares in an IP-holding. However, it is hardly possible to observe these structures in our data and the economic relevance of these structures is unclear. We are confident that we cover the most important and relevant structures in our discussion in 1.1.1., 1.1.2. and 1.1.3.
} 
borders at a later point is costly and we assume that the management optimizes the R\&D phase and the IP phase beforehand and with a view on the overall tax burden. The initial distribution of R\&D and IP, and accordingly, the distribution of patent applicants, should be shaped by taxation in the R\&D phase and in the IP phase.

\subsection{Summary and Hypotheses}

A management that maximizes the firm's value should do tax planning to keep the firm's costs and tax burden low. From a time perspective, we assume two-stages: The R\&D phase and the IP ownership phase. Tax planning to achieve a beneficial structuring for tax purposes considers the overall tax burden in both phases. Planning should be done before assigning R\&D tasks, as the potential for tax planning with R\&D and IP ownership, after having set the location for $\mathrm{R} \& \mathrm{D}$, is rather limited because transfer pricing and exit-taxation eliminate potential tax benefits. This implies that firms optimize R\&D phase and IP phase simultaneously as a trade-off between tax-effects for the former and for the latter (see Figure 5). Choosing a specific firm to invest in R\&D and, consequently, to become the entity which files the application also determines the country and the country-specific (tax) parameters. The applicant, which we observe in the data, is the relevant person to analyse tax behaviour as he initially bears the R\&D costs and bears the tax effects in the R\&D phase, acquires IP ownership and bears the tax effects in the IP phase in the above described structures.

Figure 5: Decision-Tree for R\&D investment and Patenting.

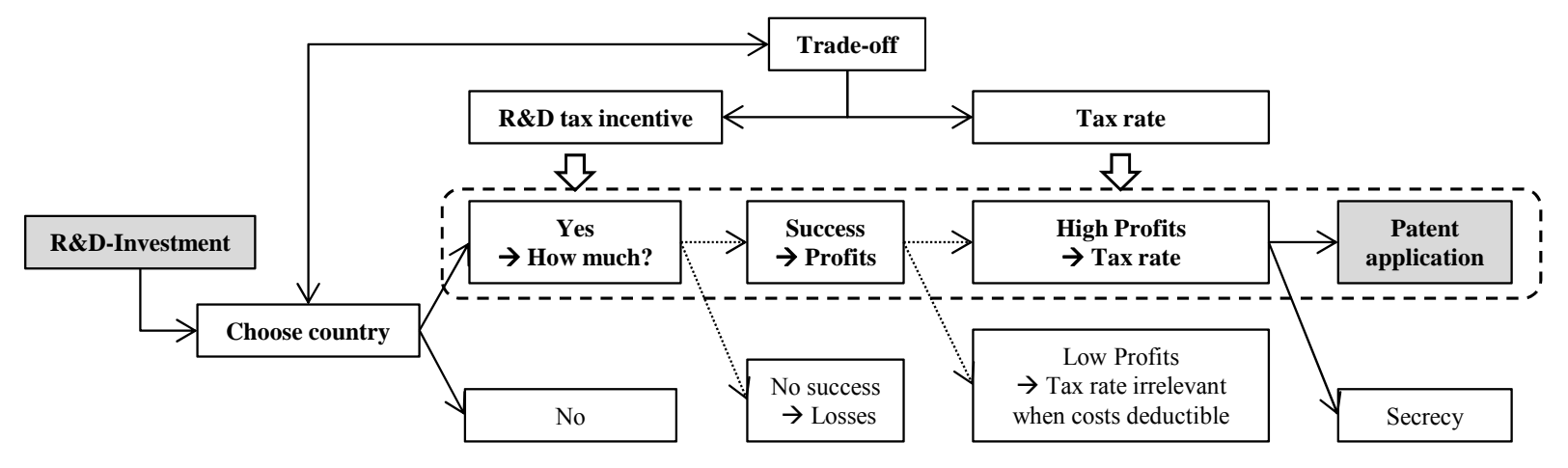

Source: Own illustration.

A firm that maximizes the firm value and faces lower user costs for R\&D should invest more in $R \& D$ projects and vice versa. The management should furthermore optimize the tax effects in the R\&D phase by managing R\&D tax-efficiently, by avoiding the capitalization of $R \& D$ costs and by using $R \& D$ tax incentives. $R \& D$ tax incentives can also be used for contract $R \& D$ across borders. The measure that captures the underlying incentives in the R\&D phase for the empirical analysis is the B-Index. We thus expect that firms invest more in R\&D and generate more patent applications when $R \& D$ tax incentives are generous and we thus expect a negative effect of the B-Index in our empirical analysis.

The firm should also optimize tax effects for the IP phase by managing patenting versus secrecy tax-efficiently and by minimizing the tax rate. Groups use several models for the 
tax-efficient structuring of their R\&D assignments and IP ownership. The measure that covers the underlying incentives in the IP phase is the combined statutory corporate income tax rate. Applications reflect successful R\&D with a positive return and we thus expect a negative effect of the combined statutory corporate income tax rate on patent applications in our empirical analysis.

\section{Data}

\subsection{Sample and Dependent Variable}

We take data from the European Patent Office's Bulletin. The EPO's Bulletin provides separate name and address details for each patent applicant and inventor. An application can be made both by natural and juridical persons and jointly with several other applicants. We extracted the applicant's name, legal form, address and country; however, we dropped applications from unincorporated entities. ${ }^{20} \mathrm{We}$ checked for abbreviations for unincorporated legal forms and checked applicants without legal form manually (those account for $9 \%$ of the applications). Standardisation of name and address, for example extraction of legal form and abbreviation of frequent words, made it possible to group applicants across years by a unique identification number and to cumulate their count of patent applications. In case we recorded no application for the identification number in a certain year, we assumed a zero as observation in case that there was an earlier EPO application of the person_id. ${ }^{21}$ The resulting panel is unbalanced and consists of "panel_ids", each representing a unique incorporated firm. The dependent variable in our study is the count of patent applications that a particular firm submitted in a specific year. ${ }^{22}$

In order to gather firm-specific information, such as the number of employees or total assets in the balance, we merge data from the Amadeus-database to the applicants. Accordingly, we had to match the addresses of the applicants in the EPO-Bulletin and the addresses in Amadeus. First, the address fields from the EPO Bulletin and Amadeus were split into name, legal form, address, city, zipcode etc. Second, these fields were harmonised in several steps in both datasets to obtain comparable sets of records, which can be compared in an automated

\footnotetext{
20 We dropped unincorporated applicants as those firms are subject to different tax rules and tax rates (income tax rather than corporate income tax) compared to incorporated firms.

21 The very first EPO application was in 1977. We set the dependent variable to missing in the years between 1977 and the first EPO application of the person_id.

22 More precisely, we sum up the firm's application shares in a specific year. We compute the sum of the firm's application shares by taking the inverse of the number of applicants of each single patent application. For example, an application was filed by firm $A$ and firm $B$, we take $1 / 2$ for firm $A$ and $1 / 2$ for firm $B$, which equals one in total. The so computed count sometimes is no whole number/integer, for example when the firm's share is 0.5 . However, this had no impact on our quantitative results. It is also possible to count each involvement of an applicant in a patent application. For example, we could count one for applicant A and one for applicant B if A and $\mathrm{B}$ are registered as patent applicants for the same patent (in total: 2). However, it turned out that the choice of the procedure was irrelevant to our quantitative results. For the sake of simplicity we refer to the variable as "count of patent applications".
} 
process. For example, typical abbreviations of legal forms in the name field were searched, extracted from the name field and harmonised. Third, a record linkage tool was applied which runs a probabilistic match algorithm involving name, legal form, address, country etc. (Blasnik (2010)). The observations with poor match results ${ }^{23}$ were checked manually. We could also significantly improve the number of matched patent applications by comparing our results to the results of a match done by Thoma et al. (2010), which was kindly provided to us. Descriptive statistics can be found in Table 1, Table A-4 and Table A-5. We analyse applications with a priority date, which is in most cases equal to the date of the application, between 1998 and 2007 as our firm data is available from 1998 onwards only.

Table 1: Identification process between EPO Bulletin and AMADEUS (count of applicants)

\begin{tabular}{|c|c|c|c|c|c|}
\hline \multirow[t]{2}{*}{\begin{tabular}{|l|} 
Patent applications \\
Year of Priority \\
\end{tabular}} & \multirow[t]{2}{*}{$\begin{array}{c}\text { EPO applications } \\
\text { from EEA states } \\
\text { (Source: EPO Bulle- } \\
\text { tin) } \\
\text { Sum }\end{array}$} & \multicolumn{2}{|c|}{$\begin{array}{l}\text { Applications matched } \\
\text { with AMADEUS }\end{array}$} & \multicolumn{2}{|c|}{$\begin{array}{c}\text { Applications matched with } \\
\text { AMADEUS and with full firm- } \\
\text { specific and country specific varia- } \\
\text { bles }\end{array}$} \\
\hline & & Mean & Sum & Mean & Sum \\
\hline 1998 & 46,579 & 1.18 & 33,057 & 2.42 & 12,218 \\
\hline 1999 & 50,979 & 1.19 & 36,219 & 2.77 & 17,496 \\
\hline 2000 & 53,852 & 1.16 & 38,328 & 2.49 & 16,757 \\
\hline 2001 & 53,702 & 1.10 & 38,603 & 2.33 & 18,434 \\
\hline 2002 & 53,982 & 1.05 & 38,729 & 2.01 & 15,582 \\
\hline 2003 & 55,278 & 1.01 & 39,040 & 2.01 & 16,750 \\
\hline 2004 & 57,859 & 0.99 & 39,902 & 1.98 & 15,040 \\
\hline 2005 & 59,434 & 0.97 & 40,556 & 1.90 & 18,121 \\
\hline 2006 & 60,550 & 0.94 & 40,909 & 1.90 & 20,414 \\
\hline 2007 & 33,874 & 0.51 & 22,296 & 1.06 & 11,133 \\
\hline Total & 526,087 & 0.99 & 367,639 & 2.01 & 161,945 \\
\hline
\end{tabular}

In total, we were able to identify $69.9 \%(=367,639 / 526,087)$ of the applications to the EPO from applicants in EEA member states (EEA states state our basic population). The identification ratio by country, however, varies across countries (Table A-4). The 5 largest EU countries by population are, for example, covered at rates between $51 \%$ for Spain and $74 \%$ for the United Kingdom. Differences in the identification process can be attributed to characteristics of the applicants like size, group structures, history of applying at the EPO and coverage by the Amadeus-database. We use observations only if we can specify the number of employees and total assets of the individual firm to control for firm-specific time-variant effects. The basic estimation sample, therefore, consists of 80,484 observations. Each observation represents the count of applications in a specific year for a specific firm. We would, for example, observe " 3 " for firm A in 2000 if firm A would have done 3 patent applications in the year 2000. The observations spread over twenty countries ${ }^{24}$ for the years 1998 to 2007. Altogether,

\footnotetext{
23 Poor matches were defined as matches where name and address were unequal (no perfect match of the names and address fields) but the similarity was greater than (approx.) 0.66 (on a scale from 0 to 1 , with 1 - indicating a perfect match) in the probabilistic match algorithm.

24 Which are AT, BE, CZ, DE, DK, ES, FI, FR, GB, GR, HU, IE, IT, LU, NL, NO, PL, PT, SE, SK. Switzerland is excluded from the study as the combined tax rate varies across the 26 cantons and several specific tax regimes exist, especially for IP holding corporations. We can neither reliably observe the canton nor the beneficial tax regime.
} 
the count of all patent applications in the sample is 161,945 (Table 1, column 6), which results in an average of $2.01(=161,945$ / 80,484) applications for each firm in our sample per year. The average numbers of patent applications (mean) in Table 1 decrease slightly from 1998 onwards indicating that the identified applicants are slightly biased towards larger corporations in earlier years as those larger companies are more likely recorded in Amadeus. Table 2 provides statistics of the basic sample, that we use for the regressions.

Table 2: Summary statistic (pooled).

\begin{tabular}{|c|c|c|c|c|c|c|c|c|}
\hline Variable & $\begin{array}{l}\text { Description / Scale in } \\
\text { summary table }\end{array}$ & Unit & Obs & Mean & Std. Dev. & Min & Max & $\begin{array}{l}\text { Scale in } \\
\text { regression }\end{array}$ \\
\hline Patent Applications & Number & & 80,484 & 2.012 & 23.015 & 0.000 & 2,064 & \\
\hline Comb. Corp. Stat. Tax & $0-1$ scale & $\mathrm{C}$ & & & & & & \\
\hline Rate & & & 80,484 & 0.336 & 0.046 & 0.125 & 0.560 & \\
\hline EATR & $0-1$ scale & $\mathrm{C}$ & 80,484 & 0.313 & 0.043 & 0.094 & 0.412 & \\
\hline EATR (Intangibles) & $0-1$ scale & $\mathrm{C}$ & 80,484 & 0.281 & 0.040 & 0.093 & 0.380 & \\
\hline B-Index (large) & & $\mathrm{C}$ & 80,484 & 0.938 & 0.136 & 0.428 & 1.069 & \\
\hline GDP p. capita & $€$ (market pr.) & $\mathrm{C}$ & 80,484 & 26,577 & 5,088 & 3,700 & 60,680 & $\log$ \\
\hline Pub. R\&DStaff p. capita & Number & $\mathrm{C}$ & 80,484 & 0.0006 & 0.0003 & 0.0002 & 0.0015 & \\
\hline Students p. capita & Number (Tert Educat.) & $\mathrm{C}$ & 80,484 & 0.0360 & 0.0063 & 0.0056 & 0.0588 & \\
\hline Ginarte-Park & $\begin{array}{c}\text { (Index for patent rights, 0- } \\
5 \text { scale) }\end{array}$ & $\mathrm{C}$ & 80,484 & 4.558 & 0.145 & 2.760 & 4.670 & \\
\hline \multirow[t]{2}{*}{ Openness } & Share of Import + Export & \multirow[t]{2}{*}{$\mathrm{C}$} & & & & & & \\
\hline & to GDP & & 80,484 & 0.567 & 0.299 & 0.180 & 2.240 & \\
\hline High-tech export & Share of GDP & $\mathrm{C}$ & 80,484 & 0.054 & 0.036 & 0.004 & 0.375 & \\
\hline \multirow{2}{*}{$\begin{array}{c}\text { Governm. funded } \\
\text { BERD }\end{array}$} & \multirow[t]{2}{*}{ Share of GDP } & \multirow[t]{2}{*}{$\mathrm{C}$} & & & & & & \\
\hline & & & 80,484 & 0.0009 & 0.0004 & 0.0000 & 0.0022 & \\
\hline Firm-specific & Number & $\mathrm{F}$ & & & & & & $\log$ \\
\hline Employees & \multirow{3}{*}{$€$ Mio. } & \multirow{3}{*}{$\mathrm{F}$} & 80,484 & $1,244.756$ & 10,446 & 1 & 502,763 & \\
\hline Firm-specific & & & & & & & & \multirow[t]{2}{*}{$\log$} \\
\hline Total Assets & & & 80,484 & 488.020 & 5,298 & 0 & 277,720 & \\
\hline
\end{tabular}

Notes: "Log" indicates that the variable is put in natural logarithm in the regression. "C" denotes country specific variables and "F" denotes firm-specific variables. Firms showing zero patent applications in all years (1998 to 2007) were dropped as they also drop out of the fixed-effects regressions.

\subsection{Tax Variables}

We use the synthetic measure $B$-Index to gauge tax induced changes in the user cost of R\&D capital (Methodology according to McFetridge and Warda (1983a); Warda (1990); Guellec and van Pottelsberghe de la Potterie (2003) / Source: Own calculations; details in Tables A-2 and A-3). Lower values of the B-Index, for example as a result of a tax credit for R\&D, indicate a lower threshold for the minimum return for $\mathrm{R} \& \mathrm{D}$ investments. Thus, a lower B-Index is supposed to trigger more $R \& D$ investments and resulting patents. The Index is a frequently used approach; Guellec and Pottelsberghe (2003), Falk (2006), Baghana and Mohnen (2009) and Wilson (2009), for example, rely on this methodology. The B-Index measure does not account for tax exhaustion or thresholds above which the incentive is not granted and is, thus, imprecise for R\&D tax incentives with thresholds or firms generating losses. Thresholds exist in most countries. Therefore, the index might reveal a lower explanatory power in the regression for firms with R\&D budgets above those country-specific thresholds, which range between $€ 110 \mathrm{~K}$ in the Netherlands and $€ 16 \mathrm{M}$ in France. Other examples are $€ 15 \mathrm{M}$ in Italy, 35\% of corporate income tax in Spain or the amount of social security contributions and wage withholding tax in the UK. 
We also use combined statutory corporate income tax rates ("corporate income tax rate") (Source: OECD, Taxation of Corporate and Capital Income) to cover the taxation of profits from IP. The rates include central and regional statutory tax rates. They capture an important parameter for multinational groups when it comes to a location decision (Buettner und Ruf (2007); Devereux (2007); Russo et al. (2007): 94-98). The combined statutory corporate income tax rate represents an appropriate measure for the tax burden of specifically profitable investments as the tax deductible costs, which would reduce the taxable base, are neglected. The combined statutory corporate income tax rate does not account for the tax shield from financing and focuses only on the taxation of returns. Correlation between B-Index and the combined statutory corporate income tax rate in our sample is small (0.02). Attractive tax conditions for production and supporting activities for R\&D, like capital allowances for machinery, buildings and intangible assets, can also shape the competitiveness of a location since R\&D is often associated with production and technical assignments. Therefore, we also test whether the determination of the tax base has an effect. For this purpose, we use the effective average tax rate (EATR) in a sensitivity analysis. We also use EATR (Intangibles), which is calculated specifically for an investment into intangible assets like patents (Source for both EATR: Devereux et al. (2009)). ${ }^{25}$ Both EATRs provide a measure accounting for tax accounting rules, such as capital allowances, in addition to the tax rate. Both apply a weighted average for financing: retained earnings, debt and new equity. ${ }^{26}$ The B-Index assumes selffinancing. Correlations between EATR and the B-Index (0.31) and EATR (Intangibles) and the B-Index (0.40) are thus stronger. Therefore, the combined statutory corporate income tax rate seems to be the preferable measure in combination with the B-Index and we use EATR and EATR (Intangibles) only for a sensitivity analysis.

\subsection{Firm- and Country-Specific Control Variables}

We include year-dummies to cover technological and global changes. Firm-specific parameters like the available workforce are important control variables. Thus, we use the firm-yearspecific number of employees (in natural logarithm $=\log$ ) and the amount of total assets (in $\log$ ) from the balance sheet to cover effects from size and capital intensity. ${ }^{27}$ Furthermore, we add GDP per capita as a control for living standard, market size and cost effects (Lederman and Maloney (2003)). ${ }^{28} \mathrm{We}$ include the number of students enrolled in tertiary education

\footnotetext{
25 We refer to Devereux and Griffith (1999) and Devereux and Griffith (2003) for the definition of the EATR.

26 The means of both EATRs are lower compared to the statutory corporate income tax rates as debt financing are generates deductible expenses. The level of the shareholder is neglected.

27 We complete the number of employees and total assets in some cases with the respective numbers from the consolidated account of the firm to obtain a larger sample. We do that only if the firm-specific numbers in the Amadeus-database are not recorded for the whole period and if the firm is also equal to the parent company of the group according to the recorded global ultimate owner in Amadeus.

28 Sources: GDP per capita: Eurostat, GDP at market prices / Hourly Compensation Costs: Bureau of Labor Statistics at the Department of Labor, International Comparisons of Hourly Compensation Costs in Manufactur-
} 
(Bebczuk (2002)) and divide it by population to measure effects from available human capital. Public R\&D staff per capita represents the sum of full time equivalents for personnel engaged in R\&D in the public sector of the host country (Cantwell and Piscitello (2005)) divided by population. The strength of patent protection differs across countries and can affect the location decision. We therefore add an index called Ginarte-Park for patent protection, which we find in Park (2008) and which is scaled from 0 (low protection) to 5 (high protection) (Kumar (1996); Ginarte and Park (1997)). As the index is only available quinquennially, we assume that the index changes at the beginning of each five-year period in 1995, 2000, 2005. We also use a variable covering the openness of a country in successfully trading with the rest of the world to capture possible relations between innovation and trade performance (Wakelin (1998)). We calculate openness as imports and exports in goods divided by GDP. We use the share of high-tech exports as a measure to capture effects from trade and innovation, consisting of exports in the so-defined high-tech sectors aircraft and spacecraft, radio, television and communication, office, accounting and computing machinery, pharmaceuticals and medical, and precision and optical instruments divided by GDP.

\section{Estimation Analysis}

We analyse the impact of relevant parameters on the patenting behaviour ${ }^{29}$, but we are mainly interested in the effects of the tax variables. There are two reasons to further refine our analysis: First, the innovation process is characterised by nonlinearities as the first innovation is possibly more complex than the following ones (Crepon and Duguet (1997): 360). Second, the theory on international capital formation separates investment decisions into a discrete location choice (extensive margin) and the choice of investment volume (intensive margin) (See Keuschnigg (2007) for a discussion of tax effects). Along the lines of that split, we assume that intellectual capital formation with the underlying R\&D activity and intellectual capital production can also be regarded as providing a discrete investment choice (or extensive margin) and a choice of investment volume (or intensive margin). Hence, we assume two decision problems: First, the discrete investment choice for $R \& D$ and intellectual capital is represented by the binary choice of the firm to invest in $R \& D$ and is measured using a variable indicating if the firm applies for a patent or not. Firms are only included if they applied at least once between 1995 and 2007. Second, the choice of the investment volume in R\&D and intellectual capital is represented by the count of applications as dependent variable.

\footnotetext{
ing, converted to Euro / Number of students enrolled in tertiary education: OECD, Students enrolled by type of institution / Public R\&D staff per capita: Source for public R\&D staff: OECD, MEI, Total Business Enterprise R\&D personnel (FTE); OECD, R\&D personnel by sector of employment and field of science, government sector (FTE)) / Openness: Source for Imports and Exports: OECD, STAN Imports - Exports of Goods / High-tech exports: Source for exports in high-tech sectors: OECD, MSTI.

29 However, there are some inventions like process innovations that might better be kept secret instead of applying for a patent. Also, software can not be patented in Europe. Our results are therefore valid for industries with patentable inventions.
} 


\subsection{Model}

According to the above proposed split, we first analyse the binary choice whether to invest in R\&D or not and, as a result, the location of IP in a specific firm. Choosing a specific firm to invest in R\&D and, consequently, to become the entity which files the application also determines the country and the country-specific (tax) parameters. We apply a logit model to model the probability of observing an application of the firm in a year, conditional on the observed frequency of the firm's applications in all years (Chamberlain (1984); Buettner and Ruf (2007)). ${ }^{30}$ Our dependent variable for the regression is zero if the firm's count of patent applications in the year equals zero and one otherwise.

The second analysis is based on the count of applications of the specific firm per year. The dependent variable displays the characteristics of count data as there are no negative numbers and larger numbers are rare. The mean of the count of applications is below its unconditional variance. We also find a reasonable amount of zeros ${ }^{31}$, which is a common characteristic of such count data and indicates overdispersion. ${ }^{32}$ A negative binomial (NB) model relaxes the assumption of equidispersion and allows variance and mean to differ, thereby being an appropriate model to account for overdispersion (Baltagi (2001): 336; Cameron and Trivedi (2010): 641). Negative binomial models originated from analyses of patenting behaviour (Hausman et al. (1984); Crepon and Duguet (1997); Cameron and Trivedi (2001): 337; Cantwell and Piscitello (2005)). Like other studies, we apply a negative binomial (II) model which assumes a quadratic variance function $\left(\operatorname{Var}(\mathrm{y} \mid \mathrm{x})=\mathrm{E}(\mathrm{y} \mid \mathrm{x})+\alpha^{2 *} \mathrm{E}(\mathrm{y} \mid \mathrm{x})\right)$. It also accounts for unobserved firm-specific effects and, thus, captures differences among firms in the patenting decision (Crepon and Duguet (1997)), which may stem from technological opportunities or special know-how. Negative binomial models also avoid problems with cluster-robustness (Cameron and Trivedi (2010): 641).

We use panel models with fixed-effects specifications at the firm level to overcome problems with country and firm-specific unobservable effects as the patenting process can be affected by country-specific effects, for example public infrastructure, and by firm-specific effects, for example the quality of management. The level of taxation is usually positively correlated with the level of public services but it is difficult to observe quality and quantity of

\footnotetext{
30 The analysis explains the patent location decision where it is subject to some variation over time and not determined beforehand (firm-fixed). The fixed-effect specification of the logit model drops the firm from the analysis if the firm-fixed effect is paramount in a way that all binary decisions between 1998 and 2007 are either yes or no (equal zero or one).

31 The share of observed zeros in the basic sample is $61 \%$ and comparable to other publications on patents $(60 \%$ in Bound et al. (1984); 73\% in Crepon and Duguet (1997)).

32 Overdispersion can, among other reasons, occur if the process responsible for the first patent application is different from the process for further applications (see Baltagi (2001), p. 337). In order to test for overdispersion, we apply a likelihood ratio test as applied in Stata Library online, "Analyzing Count Data". The $\alpha$ - coefficient in the variance function is significantly different from zero, indicating overdispersion. We additionally test the null hypothesis of equidispersion based on the variance function of a negative binomial (II) model using a t-test (see Cameron and Trivedi (2010), p. 575) and the outcome also indicates overdispersion.
} 
public infrastructure (Bartik (1991); Phillips and Goss (1995)), for example public R\&D. Unobservable characteristics of the firm, such as innovativeness and strategic patenting, determine the firm's propensity to patent and are difficult to observe as well (Scherer (1983)). The fixed-effects specification captures time-invariant firm-characteristics, like industry or degree of technological capabilities. ${ }^{33}$ It also relaxes the assumption of independence and allows for correlation between taxes, tax incentives for R\&D and other variables (Mundlak (1978); Examples are Buettner and Ruf (2007) and Karkinsky and Riedel (2009)). ${ }^{34}$

In our estimation strategy, we therefore first apply a logit model. Second, we exclude zero-observations and run a negative binomial (II) hurdle model restricted (truncated) to observations larger than zero (see for example Cameron and Trivedi (2010): $583 \mathrm{f}$.) to further analyse the count of applications. Third, we include the zero-observations again and run the negative binomial (II) model on the whole sample with all observations.

\subsection{Results}

According to our estimation strategy outlined in the beginning of chapter 3 and 3.1, we treat the application as a binary choice to locate R\&D and IP ownership in a specific firm in a first step and run a logit model with firm-fixed effects. The model in specification 1 in Table 3 contains a reduced set and the model in specification 2 contains a basic set of control variables. Focusing on the tax variables, we find a significant negative effect of the B-Index in both specifications. This reveals the expected negative effect of the R\&D user cost on patenting and indicates, according to our assumptions, a positive effect of $R \& D$ tax incentives on $R \& D$ investment. Quantitatively, a decrease of the B-Index by one percentage point would increase the odds ratio by 0.011 according to our estimates (marginal effect -1.1 , evaluated at the mean of all variables), which translates in a $11 \%$ increase of that odds ratio for a ten percentage point decrease of the B-Index. Such a decrease can be achieved, for example, by the introduction of a tax credit of $10 \%$ on all $\mathrm{R} \& \mathrm{D}$ expenditures. The odds ratio is the ratio of the probability to observe a patent application divided by the probability to observe no application. The combined statutory corporate income tax rate shows the assumed negative impact in specification 1 and a positive impact in specification 2, but is not significant in both cases. ${ }^{35}$

\footnotetext{
33 Patent indicators also have some disadvantages (e.g. Pavitt (1985)). There are different propensities to patent across industries. Potential applicants might also prefer secrecy or lead time over patenting (Cohen et al. (2000)). This is of minor importance to our analysis as we control for firm-fixed-effects and capture time-fixed behaviour in our following analysis.

34 Hausman-tests confirm the use of fixed-effects specifications for logit and NB (II). We also include year dummies to control for year-specific effects and we include the relevant variables to control for time-variant country-specific effects. We do not observe firms moving from one location to another and, thus, refrain from also controlling for location-specific fixed-effects besides firm-specific fixed-effects as this would drop the tax variables from the regression.

35 Focusing on the control variables, we find that the firm-specific number of employees and the total assets show a reasonable, significant and positive effect in both logit specifications (1 and 2). The number of employees and total assets reflect the potential to develop and generate intellectual capital. Ginarte-Park reflects the
} 
Table 3: Main regression results.

\begin{tabular}{|c|c|c|c|c|c|c|c|}
\hline Specification & 1 & 2 & 3 & 4 & 5 & 6 & 7 \\
\hline Model & LOGIT & LOGIT & $\mathrm{NB}(\mathrm{II})$ & $\mathrm{NB}(\mathrm{II})$ & NB(II) & NB(II) & $\mathrm{NB}(\mathrm{II})$ \\
\hline Fixed-effects? & fixed-effects & fixed-effects & fixed-effects & fixed-effects & fixed-effects & fixed-effects & fixed-effects \\
\hline Dependent Variable & $\begin{array}{l}\text { Patent applica- } \\
\text { tion: yes/no }\end{array}$ & $\begin{array}{l}\text { Patent applica- } \\
\text { tion: yes/no }\end{array}$ & $\begin{array}{c}\text { Count of ap- } \\
\text { plications } \\
\text { \# App. }>0\end{array}$ & $\begin{array}{c}\text { Count of ap- } \\
\text { plications }\end{array}$ & $\begin{array}{c}\text { Count of ap- } \\
\text { plications }\end{array}$ & $\begin{array}{c}\text { Count of ap- } \\
\text { plications }\end{array}$ & $\begin{array}{c}\text { Count of ap- } \\
\text { plications }\end{array}$ \\
\hline $\begin{array}{c}\text { Comb. Corp. Stat. Tax Rate } \\
\text { EATR }\end{array}$ & $\begin{array}{l}-0.224 \\
(0.594)\end{array}$ & $\begin{array}{l}0.653 \\
(0.662)\end{array}$ & $\begin{array}{c}-0.844 * * * \\
(0.241)\end{array}$ & $\begin{array}{c}-0.744 * * * \\
(0.203)\end{array}$ & $\begin{array}{c}-0.862 * * * \\
(0.235)\end{array}$ & $\begin{array}{l}-0.268 \\
(0.367)\end{array}$ & \\
\hline EATR (Intangibles) & & & & & & & $\begin{array}{c}0.361 \\
(0.360)\end{array}$ \\
\hline B-Index (Large) & $\begin{array}{c}-1.184 * * * \\
(0.311)\end{array}$ & $\begin{array}{c}-1.070 * * * \\
(0.324)\end{array}$ & $\begin{array}{c}-0.0560 \\
(0.157)\end{array}$ & $\begin{array}{c}0.517 * * * \\
(0.135)\end{array}$ & $\begin{array}{l}0.192 \\
(0.143)\end{array}$ & $\begin{array}{l}0.200 \\
(0.145)\end{array}$ & $\begin{array}{l}0.256^{*} \\
(0.147)\end{array}$ \\
\hline Log. GDP p. capita & $\begin{array}{c}-1.700 * * * \\
(0.365)\end{array}$ & $\begin{array}{c}-1.895^{* * * *} \\
(0.391)\end{array}$ & $\begin{array}{c}-0.0925 \\
(0.141)\end{array}$ & $\begin{array}{c}-0.221 * * \\
(0.106)\end{array}$ & $\begin{array}{c}-0.228 * * \\
(0.113)\end{array}$ & $\begin{array}{c}-0.322 * * * \\
(0.111)\end{array}$ & $\begin{array}{c}-0.346^{* * * *} \\
(0.109)\end{array}$ \\
\hline Public R\&D staff p. capita & & $\begin{array}{c}792.3 * * * \\
(171.9)\end{array}$ & $\begin{array}{l}-16.86 \\
(66.47)\end{array}$ & & $\begin{array}{c}267.7 * * * \\
(58.51)\end{array}$ & $\begin{array}{c}257.0 * * * \\
(60.24)\end{array}$ & $\begin{array}{c}232.2 * * * \\
(59.96)\end{array}$ \\
\hline Students p. capita & & -13.15 & -4.729 & & $-16.27 * * *$ & $-14.15^{* * *}$ & $-12.57 * * *$ \\
\hline (Tert. edu.) & & $(8.315)$ & $(3.191)$ & & $(2.854)$ & $(2.922)$ & $(2.876)$ \\
\hline Ginarte-Park & & $\begin{array}{c}0.424 * * \\
(0.173)\end{array}$ & $\begin{array}{c}0.281 * * * \\
(0.0938)\end{array}$ & & $\begin{array}{c}0.316^{* * *} \\
(0.0854)\end{array}$ & $\begin{array}{c}0.407 * * * \\
(0.0814)\end{array}$ & $\begin{array}{c}0.420 * * * \\
(0.0818)\end{array}$ \\
\hline Openness & & $\begin{array}{c}0.237 \\
(0.319)\end{array}$ & $\begin{array}{l}0.0877 \\
(0.122)\end{array}$ & & $\begin{array}{c}0.228 * * \\
(0.107)\end{array}$ & $\begin{array}{l}0.187^{*} \\
(0.107)\end{array}$ & $\begin{array}{l}0.196^{*} \\
(0.107)\end{array}$ \\
\hline High-Tech export share & & $\begin{array}{c}-0.0624 \\
(1.940)\end{array}$ & $\begin{array}{c}-1.618 * * \\
(0.818)\end{array}$ & & $\begin{array}{l}-0.403 \\
(0.751)\end{array}$ & $\begin{array}{c}0.151 \\
(0.755)\end{array}$ & $\begin{array}{c}0.426 \\
(0.736)\end{array}$ \\
\hline $\begin{array}{c}\text { Governments } \\
\text { funding on BERD }\end{array}$ & & $\begin{array}{c}-161.7^{*} \\
(83.55)\end{array}$ & $\begin{array}{l}1.757 \\
(36.79)\end{array}$ & & $\begin{array}{c}-89.78 * * * \\
(34.24)\end{array}$ & $\begin{array}{c}-79.77 * * \\
(35.42)\end{array}$ & $\begin{array}{c}-61.50 * \\
(35.60)\end{array}$ \\
\hline Log. Employees & $\begin{array}{c}0.0673 * * * \\
(0.0189)\end{array}$ & $\begin{array}{c}0.0627 * * * \\
(0.0189)\end{array}$ & $\begin{array}{l}-0.00269 \\
(0.00762)\end{array}$ & $\begin{array}{l}0.0494 * * * \\
(0.00834)\end{array}$ & $\begin{array}{c}0.0471 * * * \\
(0.00831)\end{array}$ & $\begin{array}{c}0.0461 * * * \\
(0.00829)\end{array}$ & $\begin{array}{c}0.0455 * * * \\
(0.00828)\end{array}$ \\
\hline Log. Total Assets & $\begin{array}{c}0.0765 * * * \\
(0.0225)\end{array}$ & $\begin{array}{c}0.0757 * * * \\
(0.0226)\end{array}$ & $\begin{array}{c}-0.0667 * * * \\
(0.00810)\end{array}$ & $\begin{array}{c}0.0116 \\
(0.00866)\end{array}$ & $\begin{array}{l}0.00710 \\
(0.00860)\end{array}$ & $\begin{array}{l}0.00634 \\
(0.00859)\end{array}$ & $\begin{array}{l}0.00564 \\
(0.00857)\end{array}$ \\
\hline Log likelyhood & 74,362 & 74,362 & 24,419 & 80,484 & 80,484 & 80,484 & 80,484 \\
\hline Observations & $-25,212$ & $-25,190$ & $-30,180$ & $-58,595$ & $-58,549$ & $-58,555$ & $-58,555$ \\
\hline Number of panel_id & 12,191 & 12,191 & 6,823 & 13,512 & 13,512 & 13,512 & 13,512 \\
\hline
\end{tabular}

Notes: Standard errors are in parentheses $\left(* * * \mathrm{p}<0.01, * * \mathrm{p}<0.05,{ }^{*} \mathrm{p}<0.1\right) .{ }^{2}$ The NB (II) model accounts for overdispersion and is close to cluster-robust estimation (see Cameron/Trivedi 2010, p. 641). "Log" indicates natural logarithm. Time controls (Year dummy) included. "Observations" indicates firm-year observations of the count of applications per year. "Number of panel_id" indicates the number of different firms that are observed in the panel over several years, each panel_id thus can represent up to 10 "observations".

In the second step, we separate the decision to apply for a patent (yes/no) and the intensive decision (count of applications) to allow that the zeros and non-zeros are determined by different underlying economic processes. Therefore, we compute a logit model equal to specification 2 in Table 3, like already discussed above. We then use a negative binomial (II) model which we restrict to count-observations larger than zero (Table 3, specification 3). The NB (II) model is, thus, truncated at zero and we can analyse the factors which determine the count of patent applications given that the firm had at least one application in that year. In specification 3, we find no significant effect of the B-Index. The fact that the B-Index is significant for the binary decision (specification 2) but not for the intensive decision (count

strength of patent protection and it reveals a reasonable significant positive impact on patenting. Furthermore, Public R\&D staff reveals a significant positive effect which is intuitive as public institutions provide important infrastructure. GDP per capita shows a significant negative effect in both logit specifications as it captures wealth effects and the market attractiveness but also costs for labour inputs and, thus, could capture unfavourable cost effects. Other variables (Openness, High-Tech export) are insignificant. Students per capita and the government's funding on BERD show significant negative effects. An explanation could be the frequently high selectivity of direct governmental subsidies for R\&D projects with subsequent crowding out of unfortunate applicants for direct grants. 
number, specification 3) could be explained by the thresholds for benefits from R\&D tax incentives (as discussed in chapter 2.2.). Incentives might become irrelevant for larger firms as they exceed the thresholds with their R\&D budgets. Furthermore, tax incentives could increase the probability of smaller firms to do continuous $R \& D$, whereas larger firms have enough funds. This might rather increase the ability of smaller firms to overcome the obstacles to innovation and it might thus increase the number of firms which continuously invest in R\&D. Moreover, the link between the scale of R\&D tax subsidies and the scale of patent output might be less resilient than expected.

In addition, we find a significant negative effect of the combined statutory corporate income tax rate on the number of applications in specification 3. The observed negative effect is in line with our expectations in chapter 1 . It can be explained by decreased real R\&D activity as the country becomes less attractive to locate R\&D projects after considering taxation of the resulting IP. A higher tax rate makes it more attractive to relocate R\&D activity to other countries with lower tax rates in the course of tax planning with R\&D phase and IP phase. Furthermore, tax-efficient behaviour, for example by using secrecy instead of patenting or by deferring patent applications could be reasons. We find a marginal effect of -0.8 , which means that the average number of applications increases by 0.08 for a ten percentage point decrease of the tax rate.

\subsection{Sensitivity Analyses}

We now abandon the separate analysis of extensive and intensive decision and apply the negative binomial (II) model to the whole sample, which means to all observations regardless if the firms apply for zero or more patents (Table 3, specifications 4, 5, 6 and 7). We find a significant positive effect of the B-Index on the count of applications for the reduced set of variables (specification 4), which is unexpected but might again be explained by thresholds for R\&D tax incentives and by important control variables that are not in the reduced set of variables. ${ }^{36}$ Yet, the B-Index is not significant anymore in specification 5 with all control variables included. We find a significant negative effect of the combined statutory corporate income tax rate in this specification with a marginal effect of -0.9 , which translates in an increase of the average count of applications by 0.09 for a ten percentage point decrease of the tax rate.

Several sensitivity analyses further account for alternative tax variables and for structural heterogeneity among the patenting firms. First, we use EATR and EATR (Intangibles) as alternative tax measures for the tax burden in the IP ownership phase (Table 3, specification 6 and 7). The EATR displays negative effects and the EATR (Intangibles) displays a pos-

\footnotetext{
36 Table 3 also contains a NB (II) model with the reduced set of variables as a robustness check (specification 2). The corporate income tax rate is insignificant in this reduced model as well as total assets. Yet, the B-Index and employees display significantly positive effects.
} 
itive effect, but both are insignificant. The log likelyhood indicates that the EATR and the EATR (Intangibles) provide a worse fit of the model compared to the combined statutory corporate income tax rate. Both measures assume a mixture of three ways of financing. The assumed financing mix might fail to reproduce the real financing pattern of the firms. Thus, we prefer the combined statutory corporate income tax rate as measure for the tax burden.

Second, we exclude countries having no $R \& D$ tax incentive (for the years 1998 to 2007). Those countries are Germany, Denmark, Finland, Sweden, Slovakia and Norway (see also Table A-3). ${ }^{37}$ The results (in Table 4, specification 1) reveal a significant negative impact of the B-Index. The negative effect of the B-Index is significant in contrast to specification 5 in Table 3. We measure a marginal effect of -0.5 , which translates into an increase of the average count of patents by 0.05 for a ten percentage point decrease of the B-Index. We also find a significant negative effect of the corporate income tax rate. The marginal effect is -2.3 , which translates in an increase of the average count of applications by 0.23 for a decrease of the tax rate by ten percentage points. The fact that the B-Index and the corporate income tax rate proof highly significant and that the marginal effect for the tax rate is $156 \%$ higher compared to the full set of countries might be explained by different country-specific behaviour. Firms in countries with tax incentives seem to be more sensitive to the tax burden and react rather elastic on changes in taxation. Also, lawyers and tax advisors might be more familiar with the interactions between taxation and innovation in those countries.

Third, we check whether firms react differently if the invention was made in cooperation with inventors from foreign countries, for example if a German firm applies for a patent and there is a German and an Austrian inventor. We therefore keep applications with at least one foreign inventor and exclude applications that have solely domestic inventors (specifications 2 and 3 in Table 4). Those applications reflect that the physical R\&D activity is partly done in a foreign location. We find no significant effect for the B-Index in the logit model (specification 2) and in the negative binomial (II) model (specification 3). Tax planning in the R\&D phase with $R \& D$ incentives across borders by using contract $R \& D$ might still be uncommon as they emerged in the recent past. Furthermore, the legislation of the European Court of Justice (see footnote 18), which broadened the definition of eligible contract R\&D to include cross-border $R \& D$, is only about five years young. Therefore, contract $R \& D$ might not yet play a big role for these cross-border cooperations. However, we find a significant negative effect of the corporate income tax rate in the logit model with a marginal effect of 2.4 on the odds ratio. There is also a significant negative effect in the negative binomial (II)

\footnotetext{
37 The R\&D tax incentive must be accessible in general to all firms and it must be directed to R\&D inputs. Denmark had an allowance of $150 \%$ between 2002 and 2006. Yet, it was limited to contract R\&D expenditures to public research institutions and we, therefore, disregard this quite specific incentive. Norway provides a tax credit for R\&D at $20 \%$ since 2002 ("SkatteFUNN"). However, limitations restricted the credit to SMEcompanies without group-affiliation and we thus excluded the incentive from our survey.
} 
model with a marginal effect of -2.0 which is $120 \%$ larger than for the full sample (specification 5 in Table 3). Such line-ups across borders might provide better opportunities for taxeffcient structuring of the IP phase, for example by using purchase of ready-made IP or by shifting know-how (see discussion in 1.1.). It seems to be possible for low-tax countries to attract the location of patents although the R\&D activity was done in a foreign location. From a fiscal point of view this is interesting as those attracted intellectual assets also increase the taxable income and accordingly the fiscal tax revenue of that country. For innovation policy, it would be preferable also to attract the R\&D activity itself.

Table 4: Results for sensitivity analyses.

\begin{tabular}{|c|c|c|c|c|c|}
\hline Specification & 1 & 2 & 3 & 4 & 5 \\
\hline Model & $\mathrm{NB}(\mathrm{II})$ & LOGIT & NB(II) & $\mathrm{NB}(\mathrm{II})$ & NB(II) \\
\hline Fixed-effects? & fixed-effects & fixed-effects & fixed-effects & fixed-effects & fixed-effects \\
\hline Dependent Variable & $\begin{array}{c}\text { Count of applica- } \\
\text { tions }\end{array}$ & $\begin{array}{l}\text { Applic. with foreign } \\
\text { inventor: yes/no }\end{array}$ & $\begin{array}{l}\text { Count of applica- } \\
\text { tions with foreign } \\
\text { inventor }\end{array}$ & \begin{tabular}{|c|} 
Count of applications \\
where \#employees $>$ \\
5,000
\end{tabular} & $\begin{array}{c}\text { Count of applications } \\
\text { where \#employees }> \\
10,000\end{array}$ \\
\hline Comb. Corp. Stat. Tax Rate & $\begin{array}{c}-2.331 * * * \\
(0.489)\end{array}$ & $\begin{array}{l}-2.392^{*} \\
(1.224)\end{array}$ & $\begin{array}{c}-2.028 * * * \\
(0.602)\end{array}$ & $\begin{array}{c}-2.585 * * * \\
(0.594)\end{array}$ & $\begin{array}{c}-2.654 * * * \\
(0.696)\end{array}$ \\
\hline B-Index (Large) & $\begin{array}{c}-0.543^{* * * *} \\
(0.207)\end{array}$ & $\begin{array}{l}-0.137 \\
(0.809)\end{array}$ & $\begin{array}{l}0.535 \\
(0.467)\end{array}$ & $\begin{array}{l}0.655^{*} \\
(0.368)\end{array}$ & $\begin{array}{l}0.485 \\
(0.392)\end{array}$ \\
\hline Log. GDP p. capita & $\begin{array}{l}0.0787 \\
(0.129)\end{array}$ & $\begin{array}{l}-1.232 \\
(0.818)\end{array}$ & $\begin{array}{l}-0.399 \\
(0.403)\end{array}$ & $\begin{array}{l}0.296 \\
(0.299)\end{array}$ & $\begin{array}{c}0.454 \\
(0.358)\end{array}$ \\
\hline Public R\&D staff p. capita & $\begin{array}{c}51.96 \\
(122.1)\end{array}$ & $\begin{array}{l}456.8 \\
(350.1)\end{array}$ & $\begin{array}{l}146.6 \\
(179.5)\end{array}$ & $\begin{array}{c}418.9 * * * \\
(156.8)\end{array}$ & $\begin{array}{c}481.7 * * * \\
(182.8)\end{array}$ \\
\hline Students p. capita & $-21.36^{* * *}$ & 1.327 & 2.225 & $-20.64 * * *$ & $-29.88 * * *$ \\
\hline (Tert. edu.) & $(6.857)$ & (19.09) & $(9.558)$ & $(6.672)$ & $(7.133)$ \\
\hline Ginarte-Park & $\begin{array}{c}0.547 * * * \\
(0.103)\end{array}$ & $\begin{array}{l}0.0877 \\
(0.384)\end{array}$ & $\begin{array}{l}0.0567 \\
(0.262)\end{array}$ & $\begin{array}{c}0.784 * * * \\
(0.237)\end{array}$ & $\begin{array}{c}0.644 * * \\
(0.267)\end{array}$ \\
\hline Openness & $\begin{array}{c}0.305^{* * *} \\
(0.113)\end{array}$ & $\begin{array}{c}-0.0253 \\
(0.609)\end{array}$ & $\begin{array}{l}0.275 \\
(0.223)\end{array}$ & $\begin{array}{c}0.613 \\
(0.389)\end{array}$ & $\begin{array}{c}0.902 * * \\
(0.422)\end{array}$ \\
\hline High-Tech export share & $\begin{array}{c}-2.194 * * \\
(0.865)\end{array}$ & $\begin{array}{l}-3.392 \\
(3.864)\end{array}$ & $\begin{array}{c}-2.910^{*} \\
(1.578)\end{array}$ & $\begin{array}{c}-6.058 * * * \\
(2.349)\end{array}$ & $\begin{array}{c}-6.479 * * \\
(2.545)\end{array}$ \\
\hline Governments & $-132.9 * * *$ & $335.4 *$ & $233.0 * *$ & -41.13 & 61.64 \\
\hline funding on BERD & $(49.79)$ & $(173.3)$ & $(99.24)$ & $(89.02)$ & $(107.2)$ \\
\hline Log. Employees & $\begin{array}{c}0.0396 * * * \\
(0.0106)\end{array}$ & $\begin{array}{l}0.0524 \\
(0.0368)\end{array}$ & $\begin{array}{c}0.0639 * * * \\
(0.0182)\end{array}$ & $\begin{array}{c}0.0644 * * \\
(0.0300)\end{array}$ & $\begin{array}{l}0.0307 \\
(0.0304)\end{array}$ \\
\hline Log. Total Assets & $\begin{array}{l}0.00906 \\
(0.0106)\end{array}$ & $\begin{array}{c}0.166 * * * \\
(0.0448)\end{array}$ & $\begin{array}{c}0.0852 * * * \\
(0.0212)\end{array}$ & $\begin{array}{c}-0.00458 \\
(0.0280)\end{array}$ & $\begin{array}{r}0.0174 \\
(0.0291)\end{array}$ \\
\hline Log likelyhood & 59,189 & 14,118 & 1,4751 & 9,100 & 8,477 \\
\hline Observations & $-40,935$ & $-4,755$ & $-8,307$ & $-9,328$ & $-8,172$ \\
\hline Number of panel id & 9,282 & 2,127 & 2,253 & 1,781 & 1,689 \\
\hline
\end{tabular}

Notes: See notes below Table 3. Specification 1: Countries without R\&D tax incentives (DE, DK, FI, SE, SK, NO) excluded / Specifications 2-3: Only applications with at least one foreign inventor / Specifications 4-5: Only applicants with more than 5,000 employees (specification 4) and more than 10,000 employees (specification 5).

Fourth, we test whether large firms with many employees (specification 4) react differently. We find an unexpected positive effect of the B-Index, which is significant at a low level (at 10\%), for firms larger than 5,000 employees. However, the effect turns out to be insignificant for firms with more than 10,000 employees (specification 5). Nonetheless, the corporate income tax rate reveals a significantly negative impact with a marginal effect of -2.6 for firms larger than 5,000 employees. That effect is $189 \%$ larger than for the whole sample (Table 3, specification 5). The marginal effect for firms with more than 10,000 employees (specification 5) is $200 \%$ above the whole sample. Larger firms could be more sensitive to issues of taxation and react more elastic. Moreover, tax planning could be more rewarding for 
larger firms as it needs a certain degree of know-how and a certain size to have the opportunity to behave tax-efficient. Larger firms have more options and more available locations in different countries to structure R\&D phase and IP phase with regard to the overall tax burden. ${ }^{38}$

Our results compare well with the results in other studies. Parsons and Phillips (2007) report an R\&D-elasticity of $-1.2 \%$ for the user cost of $R \& D$. We find a similar (converted) elasticity of $-1.1 \%$ for the B-Index (specification 2, Table 3). Karkinsky and Riedel (2009) report a semi-elasticity of $-2.9 \%$ on patenting for a decrease of one percentage point of the corporate income tax rate. This effect is larger than our converted semi-elasticity of $-1.9 \%$ (specification 5, Table 3) but can be explained by the different sample (larger firms, patent count cut off at 20 applications p.a., different time period).

\section{Conclusions}

We compare tax subsidies for inputs in the R\&D process and find an increasing level of tax incentives from 1998 to 2007. We use micro-level patent data of European corporations from the EPO for an empirical analysis of tax effects on the R\&D phase and on the IP phase.

We find positive effects of $R \& D$ tax incentives on the probability to invest in R\&D in the $R \& D$ phase. The marginal effect is a $11 \%$ increase of the odds ratio for a ten percentage point decrease of the $B$-Index equaling the introduction of a $10 \%$ tax credit on R\&D expenditures. $R \& D$ tax incentives seem to increase the probability of smaller firms to start investing in R\&D. We also measure an increase of the average count of patents by 0.05 for a ten percentage point decrease of the B-Index in countries with R\&D tax incentives. The statistical robustness for the B-Index in the empirical analysis beside those results is not very pronounced and may be explained by thresholds that limit the benefits from R\&D tax incentives for larger firms in many countries.

We find a negative effect of the combined statutory corporate income tax rate on the IP phase and the intensive decision which we measured with the count of patent applications. The marginal effect is estimated as an increase of the average count of applications by 0.09 for a decrease of the corporate income tax rate of ten percentage points. The effect in countries with $R \& D$ tax incentives is $156 \%$ larger indicating a stronger sensitivity to tax issues. Firms, lawyers and tax advisors might be more familiar with the interactions between taxation and innovation in those countries.

The effect of the corporate income tax rate is $120 \%$ larger for inventions that were developed in cooperation with foreign inventors. Those cooperations seem to provide better opportunities for tax planning with IP ownership in the IP phase. It seems to be possible for low-

\footnotetext{
38 We also run an ordinary least squares (OLS) regression with fixed-effects (Appendix, Table A-1) to check the robustness of our estimations. OLS is not our favourite model as it does not account for the count number properties of the data. Nevertheless, those estimations do not contradict our results. The B-Index displays negative effects (in specifications 1,2,3) but is insignificant.The corporate income tax rate as well as EATR (Intangibles) also indicate negative effects but are insignificant.
} 
tax countries to attract the location of patents although the R\&D activity was done in a foreign location. The corporate income tax rate seems to be important for those cross-border cooperations. However, it would be preferable from an innovation-policy perspective to host the physical R\&D activity itself and not only the resulting intellectual property.

Moreover, we find a marginal effect which is about $189 \%$ higher for firms with more than 5,000 employees. Larger firms have more options and more available locations in different countries to structure R\&D phase and IP phase tax-efficiently with regard to the overall tax burden. The corporate income tax rate seems to be especially important for large firms.

The results show that channels exist where fiscal policy and innovation policy can interact. A fiscal instrument to foster R\&D activity in the own country could be the use of R\&D tax incentives, which we found to have a positive effect on the probability to invest in $R \& D$ for smaller firms. Another option would be to lower the corporate income tax rate which we found to increase patent applications and, indirectly, also earlier R\&D investments in that specific country. A lower corporate income tax rate also seems to attract the location of patents that were developed in cooperation with foreign inventors which increases the fiscal tax base and the fiscal revenue of the host country. 


\section{Appendix}

Table A-1: OLS-Models, panel with fixed-effects.

\begin{tabular}{|c|c|c|c|}
\hline Specification & 1 & 2 & 3 \\
\hline Model & $\mathrm{OLS}^{3}$ & $\mathrm{OLS}^{3}$ & $\mathrm{OLS}^{3}$ \\
\hline Fixed-effects? & fixed-effects & fixed-effects & fixed-effects \\
\hline Dependent Variable & Log (Count of application) & Log (Count of application) & Log (Count of application) \\
\hline Comb. Corp. Stat. Tax Rate & $\begin{array}{c}-0.0562 \\
(0.323)\end{array}$ & & \\
\hline EATR & & $\begin{array}{l}0.0779 \\
(0.530)\end{array}$ & \\
\hline EATR (Intangibles) & & & $\begin{array}{l}-0.108 \\
(0.484)\end{array}$ \\
\hline B-Index (Large) & $\begin{array}{l}-0.135 \\
(0.181)\end{array}$ & $\begin{array}{l}-0.133 \\
(0.181)\end{array}$ & $\begin{array}{l}-0.138 \\
(0.182)\end{array}$ \\
\hline Log. GDP p. capita & $\begin{array}{c}0.144 \\
(0.239)\end{array}$ & $\begin{array}{c}0.118 \\
(0.236)\end{array}$ & $\begin{array}{c}0.143 \\
(0.233)\end{array}$ \\
\hline Public R\&D staff p. capita & $\begin{array}{l}67.27 \\
(98.88)\end{array}$ & $\begin{array}{l}67.68 \\
(98.77)\end{array}$ & $\begin{array}{l}70.57 \\
(98.48)\end{array}$ \\
\hline Students p. capita (Tert. edu.) & $\begin{array}{l}-10.41 * * \\
(4.404)\end{array}$ & $\begin{array}{c}-10.42 * * \\
(4.454)\end{array}$ & $\begin{array}{c}-10.56^{* *} \\
(4.457)\end{array}$ \\
\hline Ginarte-Park & $\begin{array}{l}0.193 * \\
(0.109)\end{array}$ & $\begin{array}{l}0.194 * \\
(0.113)\end{array}$ & $\begin{array}{l}0.198^{*} \\
(0.112)\end{array}$ \\
\hline Openness & $\begin{array}{c}0.259 \\
(0.170)\end{array}$ & $\begin{array}{c}0.271 \\
(0.179)\end{array}$ & $\begin{array}{c}0.252 \\
(0.176)\end{array}$ \\
\hline High-Tech export share & $\begin{array}{l}-1.222 \\
(1.068)\end{array}$ & $\begin{array}{l}-1.200 \\
(1.068)\end{array}$ & $\begin{array}{l}-1.223 \\
(1.068)\end{array}$ \\
\hline Governments funding on BERD & $\begin{array}{l}14.33 \\
(44.14)\end{array}$ & $\begin{array}{l}18.04 \\
(48.01)\end{array}$ & $\begin{array}{l}10.58 \\
(47.83)\end{array}$ \\
\hline Log. Employees & $\begin{array}{l}0.0204^{*} \\
(0.0115)\end{array}$ & $\begin{array}{l}0.0204^{*} \\
(0.0116)\end{array}$ & $\begin{array}{l}0.0203^{*} \\
(0.0115)\end{array}$ \\
\hline Log. Total Assets & $\begin{array}{c}0.0390^{* * * *} \\
(0.0121) \\
\end{array}$ & $\begin{array}{c}0.0391^{* * * *} \\
(0.0121)\end{array}$ & $\begin{array}{c}0.0390^{* * * *} \\
(0.0121)\end{array}$ \\
\hline R-squared & 32,192 & 32,192 & 32,192 \\
\hline Observations & 0.017 & 0.017 & 0.017 \\
\hline Number of panel_id & 14,596 & 14,596 & 14,596 \\
\hline
\end{tabular}

1998 and 2007 are included. 
Table A-2: Calculation of B-Index.

$\mathrm{B}$ is defined as $B=\frac{1-Z^{*} t}{1-t}$ where $\left(1-Z^{*} t\right)$ is the after-tax cost of a $€ 1$ expenditure in $\mathrm{R} \& \mathrm{D}$ and $t$ is the combined statutory corporate income tax rate. $\left(1-Z^{*} t\right)$ is the net present value of investments in R\&D after taxes. It covers tax treatment of input factors in the R\&D process. The value of $Z$ can be decomposed into $Z_{d}$ (net present value of depreciation), $Z_{t a}$ (net present value of special $R \& D$ tax allowances) and $Z_{c}$ (net present value of $R \& D$ tax credits). The different inputs into R\&D form together $100 \%$. The assuemd shares are $60 \%$ for labour, $30 \%$ for current costs and $10 \%$ for capital expenditures for machinery (5\%) and buildings $(5 \%) . d_{d}$ is the share of expenditures treated with a certain depreciation; $d_{t a}$ is the share of expenditures subject to an extra tax allowance for R\&D and $d_{c}$ is the share of expenditures subject to an R\&D tax credit. $Z$ can be written as a composition of $Z_{d}, Z_{t a}$ and $Z_{c}$ : $Z=d_{d} * Z_{d}+d_{t a} * Z_{t a}+d_{c} * Z_{c} * t_{c r e d i t r a t e}$. If no tax allowances or credits are available except usual depreciation, $Z$ simplifies to $Z_{d}$.

Yet, there are $\mathrm{n}$ different inputs (labour, other current and capital (machinery, buildings)) which enter the R\&D process with their specific shares $s_{n}(0.6 / 0.3 / 0.1)$. B can therefore be expressed

as:

$B=\frac{(1-Z * t)}{(1-t)}=\frac{\sum_{n} s_{n} *\left(1-Z_{n} * t\right)}{(1-t)}=\frac{\left(0.6 *\left(1-Z_{l} * t\right)+0.3 *\left(1-Z_{o c} * t\right)+0.05 *\left(1-Z_{m} * t\right)+0.05 *\left(1-Z_{b} * t\right)\right)}{(1-t)}$

If there is no specific R\&D tax incentive, $Z_{s}$ and $Z_{o c}$ for staff and other current expenditures will usually equal one as those expenditures are deductible in the same year. $Z_{m}$ (machinery) and $Z_{b}$ (buildings) cover tax depreciation for capital assets and depend on the kind of depreciation, the time to depreciate or the depreciation rate. If all $R \& D$ expenditures except buildings are deductible in the current year, then $B$ simplifies to $B=\frac{\left(0.95 *(1-t)+0.05 *\left(1-Z_{b} * t\right)\right)}{(1-t)}$. If there was an extra allowance $a_{\text {allowancerate }}$ for wages and current expenditures, it would read as $B=\frac{\left(0.90 *\left(1-\left(1+d_{t a} a\right) t\right)+0.05 *\left(1-Z_{m} * t\right)+0.05 *\left(1-Z_{b} * t\right)\right)}{(1-t)}$ when $a$ is the allowance rate. In case of a non-taxable tax credit $t_{\text {creditrate }}$, it would read $B=\frac{\left(0.90 *\left(1-d_{c} t_{\text {creditrate }}-t\right)+0.05 *\left(1-Z_{m} * t\right)+0.05 *\left(1-Z_{b} * t\right)\right)}{(1-t)}$. The calculation assumes $100 \%$ selffinancing. Warda (Warda (2001)) lists several amendments for the calculation of $\mathrm{Z}$ to account for tax credits, depreciation and allowances. For the underlying methodology see McFetridge and Warda (1983b), Warda (1990), OECD (2005); Guellec and van Pottelsberghe de la Potterie (2003). 
Table A-3: Details on R\&D tax incentives and B-Index for 1998 to 2007.

\begin{tabular}{|c|c|c|c|c|c|c|c|c|c|c|c|c|c|}
\hline $\begin{array}{l}\vec{E} \\
\hat{E} \\
0\end{array}$ & ప్ర & 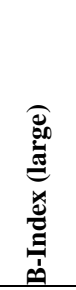 & 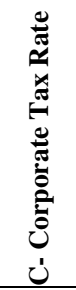 & & 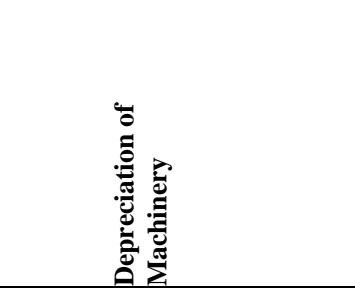 & & 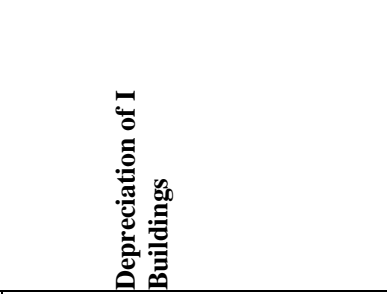 & 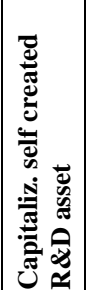 & 芯 & 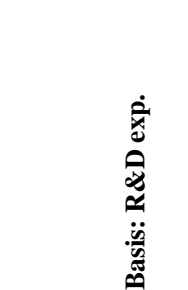 & $\frac{\mathscr{E}}{\frac{E}{0}}$ & 氖 & 莡 \\
\hline AT & 1998-1999 & 0.928 & 34.00 & SL & $14.3 \%$ & $\mathrm{SL}$ & $4.0 \%$ & No & Tax all. & Curr. \& Cap. & $18.0 \%$ & & Tax all. 9\% (Cap. (except building)) \\
\hline AT & 2000 & 0.892 & 34.00 & $\mathrm{SL}$ & $14.3 \%$ & $\mathrm{SL}$ & $4.0 \%$ & No & Tax all. & Curr. \& Cap. & $25.0 \%$ & $35.0 \%$ & Tax all. 9\% (Cap. (except building)) \\
\hline AT & 2001-2003 & 0.894 & 34.00 & $\mathrm{SL}$ & $14.3 \%$ & $\mathrm{SL}$ & $(7 \% ; 3 \% ; 3 \% \ldots)$ & No & Tax all. & Curr. \& Cap. & $25.0 \%$ & $35.0 \%$ & \\
\hline AT & 2004 & 0.895 & 34.00 & SL & $14.3 \%$ & $\mathrm{SL}$ & $3.0 \%$ & No & Tax all. & Curr. \& Cap. & $25.0 \%$ & $35.0 \%$ & \\
\hline AT & $2005-2007$ & 0.909 & 25.00 & SL & $14.3 \%$ & SL & $3.0 \%$ & No & Tax cr. & Curr. \& Cap. & $8.0 \%$ & & \\
\hline BE & 1998-2002 & 1.010 & 40.17 & SL & $33.33 \%$ (for R\&D assets) & DB & (DB $10 \%$, switch to SL at $5 \%$ ) & No & Tax all. & Cap. & $13.5 \%$ & & \\
\hline BE & 2003 & 1.007 & 33.99 & SL & $33.33 \%$ (for R\&D assets) & DB & (DB $10 \%$, switch to SL at $5 \%$ ) & No & Tax all. & Cap. & $13.5 \%$ & & $\begin{array}{l}\text { Tax cr. } 25 \% \text { (R\&D staff wage with- } \\
\text { holding tax) }\end{array}$ \\
\hline BE & 2004-2005 & 0.969 & 33.99 & SL & $33.33 \%$ (for R\&D assets) & DB & (DB $10 \%$, switch to SL at $5 \%$ ) & No & Tax all. & Cap. & $13.5 \%$ & & $\begin{array}{l}\text { Tax cr. } 25 \% \text { (R\&D staff wage with- } \\
\text { holding tax) }\end{array}$ \\
\hline BE & 2006-2007 & 0.968 & 33.99 & SL & $33.33 \%$ (for R\&D assets) & DB & (DB $10 \%$, switch to SL at $5 \%$ ) & No & Tax all. & Cap. & $14.5 \%$ & & $\begin{array}{l}\text { Tax cr. } 25 \% \text { (R\&D staff wage with- } \\
\text { holding tax) }\end{array}$ \\
\hline $\mathbf{C Z}$ & 1998 & 1.022 & 35.00 & Digi. & 6 years & Digi. & 45 years & No & & & & & \\
\hline $\mathrm{CZ}$ & 1999 & 1.019 & 35.00 & Digi. & 6 years & Digi. & 30 years & No & & & & & \\
\hline $\mathbf{C Z}$ & 2000-2003 & 1.013 & 31.00 & Digi. & 6 years & Digi. & 30 years & No & Tax all. & Cap. (machinery) & & $10.0 \%$ & \\
\hline $\mathbf{C Z}$ & 2004 & 1.012 & 28.00 & Digi. & 6 years & Digi. & 30 years & No & Tax all. & Cap. (machinery) & & $10.0 \%$ & \\
\hline $\mathrm{CZ}$ & 2005 & 0.696 & 26.00 & Digi. & 6 years & Digi. & 30 years & No & Tax all. & Curr. & & $200.0 \%$ & \\
\hline $\mathrm{CZ}$ & 2006-2007 & 0.727 & 24.00 & Digi. & 6 years & Digi. & 30 years & No & Tax all. & Curr. & & $200.0 \%$ & \\
\hline $\mathbf{D E}$ & 1998 & 1.039 & 56.52 & DB & (DB30\%;SL 8\%) & SL & $\begin{array}{l}(10 \%, 10 \%, 10 \%, 10 \%, 5 \%, 5 \%, 5 \%, 2,5 \\
\%, 2,5 \%, \ldots)\end{array}$ & No & & & & & \\
\hline DE & $1999-2000$ & 1.042 & 52.35 & DB & (DB30\%;SL 8\%) & SL & $4.0 \%$ & No & & & & & \\
\hline DE & 2001-2002 & 1.029 & 39.35 & DB & (DB20\%, switch to SL $12.8 \%$ ) & SL & $3.0 \%$ & No & & & & & \\
\hline DE & 2003 & 1.031 & 40.66 & DB & (DB20\%, switch to SL $12.8 \%$ ) & $\mathrm{SL}$ & $3.0 \%$ & No & & & & & \\
\hline DE & 2004-2005 & 1.029 & 39.35 & DB & (DB20\%, switch to SL $12.8 \%$ ) & SL & $3.0 \%$ & No & & & & & \\
\hline DE & $2006-2007$ & 1.027 & 39.35 & DB & (DB30\%;SL 8\%) & SL & $3.0 \%$ & No & & & & & \\
\hline DK & 1998 & 1.018 & 34.00 & DB & $30.0 \%$ & SL & $5.0 \%$ & No & & & & & \\
\hline DK & 1999 & 1.017 & 32.00 & DB & $30.0 \%$ & $\mathrm{Sl}$ & $5.0 \%$ & No & & & & & \\
\hline DK & 2000 & 1.017 & 32.00 & DB & $30.0 \%$ & SL & $5.0 \%$ & No & & & & & \\
\hline DK & 2001 & 1.016 & 30.00 & DB & $25.0 \%$ & $\mathrm{Sl}$ & $5.0 \%$ & No & & & & & \\
\hline DK & 2002 & 1.016 & 30.00 & DB & $25.0 \%$ & SL & $5.0 \%$ & No & & & & & \\
\hline DK & 2003 & 1.016 & 30.00 & DB & $25.0 \%$ & $\mathrm{SL}$ & $5.0 \%$ & No & & & & & \\
\hline DK & 2004 & 1.016 & 30.00 & DB & $25.0 \%$ & $\mathrm{Sl}$ & $5.0 \%$ & No & & & & & \\
\hline DK & 2005 & 1.015 & 28.00 & DB & $25.0 \%$ & SL & $5.0 \%$ & No & & & & & \\
\hline DK & 2006 & 1.015 & 28.00 & DB & $25.0 \%$ & $\mathrm{~S} 1$ & $5.0 \%$ & No & & & & & \\
\hline DK & 2007 & 1.012 & 25.00 & DB & $25.0 \%$ & $\mathrm{SL}$ & $5.0 \%$ & No & & & & & \\
\hline ES & 1998-1999 & 0.648 & 40.30 & $\overline{\mathrm{DB}}$ & (DB 28.57\%, switch to SL 8.68\%) & SL & $3.0 \%$ & No & Tax cr. & Curr. & $20.0 \%$ & $40.0 \%$ & \\
\hline ES & 2000-2001 & 0.477 & 40.30 & DB & (DB $28.57 \%$, switch to SL $8.68 \%$ ) & SL & $3.0 \%$ & No & Tax cr. & Curr. & $30.0 \%$ & $50.0 \%$ & \\
\hline ES & 2002-2003 & 0.457 & 40.30 & DB & (DB $28.57 \%$, switch to SL $8.68 \%$ ) & SL & $3.0 \%$ & No & Tax cr. & Curr. & $30.0 \%$ & $50.0 \%$ & Tax cr. (R\&D staff): $10 \%$ \\
\hline ES & 2004-2006 & 0.428 & 40.30 & DB & (DB $28.57 \%$, switch to SL $8.68 \%$ ) & $\mathrm{SL}$ & $3.0 \%$ & No & Tax cr. & Curr. & $30.0 \%$ & $50.0 \%$ & $\begin{array}{l}\text { Tax cr. (R\&D staff): } 20 \% \text { / Tax cr. } \\
\text { (machinery): } 10 \%\end{array}$ \\
\hline ES & 2007 & 0.489 & 38.01 & DB & (DB $28.57 \%$, switch to SL $8.68 \%$ ) & SL & $3.0 \%$ & No & Tax cr. & Curr. & & & \\
\hline FI & 1998 & 1.014 & 28.00 & DB & $30.0 \%$ & DB & $7.0 \%$ & No & & & & & \\
\hline
\end{tabular}




\begin{tabular}{|c|c|c|c|c|c|c|c|c|c|c|c|c|c|}
\hline $\begin{array}{l}\text { FI } \\
\text { FI } \\
\text { FI }\end{array}$ & \begin{tabular}{|c|}
1999 \\
$2000-2004$ \\
$2005-2007$ \\
\end{tabular} & $\begin{array}{l}1.015 \\
1.016 \\
1.013\end{array}$ & $\begin{array}{l}28.00 \\
29.00 \\
26.00\end{array}$ & $\begin{array}{l}\text { DB } \\
\text { DB } \\
\text { DB }\end{array}$ & $\begin{array}{l}25.0 \% \\
25.0 \% \\
25.0 \% \\
\end{array}$ & \begin{tabular}{|l} 
DB \\
DB \\
DB \\
\end{tabular} & $\begin{array}{l}7.0 \% \\
7.0 \% \\
7.0 \% \\
\end{array}$ & \begin{tabular}{|l} 
No \\
No \\
No \\
\end{tabular} & & & & & \\
\hline FR & 1998 & 0.923 & 41.67 & DB & (DB 35.71\%, switch to SL 5.49\%) & SL & $5.0 \%$ & No & Tax cr. & Curr. \& Cap. (no land) & & $50.0 \%$ & \\
\hline FR & 1999 & 0.923 & 40.00 & DB & (DB $35.71 \%$, switch to SL $5.49 \%$ ) & SL & $5.0 \%$ & No & Tax cr. & Curr. \& Cap. (no land) & & $50.0 \%$ & \\
\hline $\mathbf{F R}$ & 2000 & 0.925 & 37.76 & DB & (DB $35.71 \%$, switch to SL $5.49 \%$ ) & $\mathrm{SL}$ & $5.0 \%$ & No & Tax cr. & Curr. \& Cap. (no land) & & $50.0 \%$ & \\
\hline $\mathbf{F R}$ & 2001 & 0.926 & 36.43 & DB & (DB $32.14 \%$, switch to SL $7.07 \%$ ) & SL & $5.0 \%$ & No & Tax cr. & Curr. \& Cap. (no land) & & $50.0 \%$ & \\
\hline $\mathbf{F R}$ & 2002 & 0.926 & 35.43 & DB & (DB 32.14\%, switch to SL $7.07 \%$ ) & $\mathrm{SL}$ & $5.0 \%$ & No & Tax cr. & Curr. \& Cap. (no land) & & $50.0 \%$ & \\
\hline FR & 2003 & 0.926 & 35.43 & DB & (DB $32.14 \%$, switch to SL $7.07 \%$ ) & SL & $5.0 \%$ & No & Tax cr. & Curr. \& Cap. (no land) & & $50.0 \%$ & \\
\hline $\mathbf{F R}$ & 2004 & 0.859 & 35.43 & DB & (DB 32.14\%, switch to SL $7.07 \%$ ) & $\mathrm{SL}$ & $5.0 \%$ & No & Tax cr. & Curr. \& Cap. (no land) & $5.0 \%$ & $45.0 \%$ & \\
\hline $\mathbf{F R}$ & 2005 & 0.859 & 34.93 & DB & (DB $32.14 \%$, switch to SL $7.07 \%$ ) & $\mathrm{SL}$ & $5.0 \%$ & No & Tax cr. & Curr. \& Cap. (no land) & $5.0 \%$ & $45.0 \%$ & \\
\hline $\mathbf{F R}$ & 2006-2007 & 0.794 & 34.43 & $\mathrm{DB}$ & (DB $32.14 \%$, switch to SL $7.07 \%$ ) & $\mathrm{SL}$ & $5.0 \%$ & No & Tax cr. & Curr. \& Cap. (no land) & $10.0 \%$ & $40.0 \%$ & \\
\hline GB & 1998-2001 & 1.013 & 31.00 & SL & $100 \%$ (R\&D assets) & SL & $4.0 \%$ & No & & & & & \\
\hline GB & 2002-2007 & 0.916 & 30.00 & SL & $100 \%$ (R\&D assets) & SL & $4.0 \%$ & No & Tax all. & Curr. & $125.0 \%$ & & \\
\hline GR & 1998-2005 & 1.042 & 32.00 & DB & (DB $42.86 \%$, switch to SL $10.7 \%)$ & $\mathrm{SL}$ & $8.0 \%$ & Yes & & & & & \\
\hline GR & 2006 & 1.009 & 29.00 & DB & (DB $42.86 \%$, switch to SL $10.7 \%$ ) & $\mathrm{SL}$ & $8.0 \%$ & Yes & Tax all. & Curr. & & $50.0 \%$ & \\
\hline GR & 2007 & 1.008 & 25.00 & DB & (DB $42.86 \%$, switch to SL $10.7 \%$ ) & $\mathrm{SL}$ & $8.0 \%$ & Yes & Tax all. & Curr. & & $50.0 \%$ & \\
\hline $\mathrm{HU}$ & 1998 & 0.768 & 19.09 & SL & $14.5 \%$ & SL & $14.5 \%$ & No & Tax all. & Curr. \& Cap. (no land) & $200.0 \%$ & & \\
\hline HU & 1999 & 0.764 & 19.32 & SL & $14.5 \%$ & SL & $14.5 \%$ & No & Tax all. & Curr. \& Cap. (no land) & $200.0 \%$ & & \\
\hline HU & 2000-2002 & 0.761 & 19.55 & SL & $14.5 \%$ & $\mathrm{SL}$ & $14.5 \%$ & No & Tax all. & Curr. \& Cap. (no land) & $200.0 \%$ & & \\
\hline HU & 2003 & 0.758 & 19.55 & $\mathrm{SL}$ & $50.0 \%$ & $\mathrm{SL}$ & $14.5 \%$ & No & Tax all. & Curr. \& Cap. (no land) & $200.0 \%$ & & \\
\hline HU & 2004 & 0.788 & 17.60 & $\mathrm{SL}$ & $50.0 \%$ & $\mathrm{SL}$ & $14.5 \%$ & No & Tax all. & Curr. \& Cap. (no land) & $200.0 \%$ & & \\
\hline HU & 2005 & 0.722 & 17.52 & SL & $50.0 \%$ & $\mathrm{SL}$ & $2.0 \%$ & No & Tax all. & Curr. \& Cap. (no land) & $200.0 \%$ & & Tax cr. $10 \%$ (R\&D wages) \\
\hline HU & 2006 & 0.747 & 17.36 & SL & $50.0 \%$ & $\mathrm{SL}$ & $2.0 \%$ & No & Tax all. & Curr. \& Cap. (no land) & $200.0 \%$ & & Tax cr. $10 \%$ (R\&D wages) \\
\hline HU & 2007 & 0.690 & 21.36 & $\mathrm{SL}$ & $50.0 \%$ & $\mathrm{SL}$ & $2.0 \%$ & No & Tax all. & Curr. \& Cap. (no land) & $200.0 \%$ & & Tax cr. $10 \%$ (R\&D wages) \\
\hline IE & 1998-2000 & 1.005 & 10.00 & SL & $15.0 \%$ & $\mathrm{SL}$ & $4.0 \%$ & No & & & & & \\
\hline IE & 2001 & 1.004 & 10.00 & $\mathrm{SL}$ & $20.0 \%$ & $\mathrm{SL}$ & $4.0 \%$ & No & & & & & \\
\hline IE & 2002 & 1.003 & 10.00 & SL & $100 \%$, if R\&D cap. & $\mathrm{SL}$ & $4.0 \%$ & No & & & & & \\
\hline IE & 2003 & 1.004 & 12.50 & SL & $100 \%$, if $R \& D$ cap. & SL & $4.0 \%$ & No & & & & & \\
\hline IE & 2004 & 0.974 & 12.50 & $\mathrm{SL}$ & $100 \&$, if R\&D cap. & SL & $4.0 \%$ & No & Tax cr. & Curr. (Base 2003) & & $20.0 \%$ & Tax cr. $20 \%$ (building) \\
\hline IE & 2005 & 0.966 & 12.50 & SL & $100 \%$, if $R \& D$ cap. & $\mathrm{SL}$ & $4.0 \%$ & No & Tax cr. & Curr. (Base 2003) & & $20.0 \%$ & Tax cr. $20 \%$ (building) \\
\hline IE & 2006 & 0.958 & 12.50 & SL & $100 \%$, if R\&D cap. & $\mathrm{SL}$ & $4.0 \%$ & No & Tax cr. & Curr. (Base 2003) & & $20.0 \%$ & Tax cr. $20 \%$ (building) \\
\hline IE & 2007 & 0.950 & 12.50 & SL & $100 \%$, if R\&D cap. & $\mathrm{SL}$ & $4.0 \%$ & No & Tax cr. & Curr. (Base 2003) & & $20.0 \%$ & Tax cr. $20 \%$ (building) \\
\hline IT & 1998-2000 & 1.028 & 41.25 & \begin{tabular}{|ll} 
SL \\
\end{tabular} & $(12.5 \% ; 25 \% ; 12, \%, \ldots)$ & SL & $(4 \% ; 8 \% ; 4, \%, \ldots)$ & No & & & & & \\
\hline IT & 2001-2002 & 1.026 & 40.25 & SL & $(12.5 \% ; 25 \% ; 12, \%, \ldots)$ & $\mathrm{SL}$ & $(4 \% ; 8 \% ; 4, \%, \ldots)$ & No & & & & & \\
\hline IT & 2003 & 1.024 & 38.25 & SL & $(12.5 \% ; 25 \% ; 12, \%, \ldots)$ & SL & $(4 \% ; 8 \% ; 4, \%, \ldots)$ & No & & & & & \\
\hline IT & 2004-2006 & 0.935 & 37.25 & SL & $(12.5 \% ; 25 \% ; 12, \%, \ldots)$ & $\mathrm{SL}$ & $(4 \% ; 8 \% ; 4, \%, \ldots)$ & No & Tax cr. & Curr. \& Cap. & & $10.0 \%$ & \\
\hline IT & 2007 & 0.864 & 37.25 & SL & $(12.5 \% ; 25 \% ; 12, \%, \ldots)$ & $\mathrm{SL}$ & $(4 \% ; 8 \% ; 4, \%, \ldots)$ & No & Tax cr. & Curr. \& Cap. & & $10.0 \%$ & \\
\hline LU & 1998-2001 & 1.021 & 37.45 & DB & $\begin{array}{l}\text { (DB } 40 \% \text {, switch to SL } 8 \% \text { / for } \\
\text { R\&D) }\end{array}$ & SL & $4.0 \%$ & & & & & & \\
\hline LU & 2002-2005 & 1.016 & 30.38 & DB & $\begin{array}{l}\text { (DB } 40 \% \text {, switch to SL } 8 \% / \text { for } \\
\text { R\&D) }\end{array}$ & SL & $4.0 \%$ & & & & & & \\
\hline LU & 2006-2007 & 1.015 & 29.63 & DB & $\begin{array}{l}\text { (DB } 40 \% \text {, switch to SL } 8 \% \text { / for } \\
\text { R\&D) }\end{array}$ & SL & $4.0 \%$ & & & & & & \\
\hline NL & 1998 & 0.921 & 35.00 & SL & $14.3 \%$ & SL & $2.5 \%$ & No & Tax cr. & Wages & $17.5 \%$ & & \\
\hline NL & 1999-2001 & 0.948 & 35.00 & SL & $14.3 \%$ & $\mathrm{SL}$ & $2.5 \%$ & No & Tax cr. & Wages & $13.0 \%$ & & \\
\hline NL & 2002-2003 & 0.947 & 34.50 & SL & $14.3 \%$ & SL & $2.5 \%$ & No & Tax cr. & Wages & $13.0 \%$ & & \\
\hline NL & 2004 & 0.941 & 34.50 & SL & $14.3 \%$ & $\mathrm{SL}$ & $2.5 \%$ & No & Tax cr. & Wages & $14.0 \%$ & & \\
\hline NL & 2005 & 0.938 & 31.50 & $\mathrm{SL}$ & $14.3 \%$ & $\mathrm{SL}$ & $2.5 \%$ & No & Tax cr. & Wages & $14.0 \%$ & & \\
\hline $\mathrm{NL}$ & 2006 & 0.936 & 29.60 & SL & $14.3 \%$ & $\mathrm{SL}$ & $2.5 \%$ & No & Tax cr. & Wages & $14.0 \%$ & & \\
\hline NL & \begin{tabular}{|l}
2007 \\
\end{tabular} & 0.933 & 25.50 & SL & $14.3 \%$ & $\mathrm{SL}$ & $2.5 \%$ & No & Tax cr. & Wages & $14.0 \%$ & & \\
\hline NO & \begin{tabular}{|l|}
$1998-1999$ \\
\end{tabular} & 1.041 & 28.00 & DB & $20.0 \%$ & DB & $5.0 \%$ & & & & & & \\
\hline NO & 2000 & 1.042 & 28.00 & DB & $20.0 \%$ & DB & $4.0 \%$ & Yes & & & & & \\
\hline NO & 2001 & 1.044 & 28.00 & DB & $15.0 \%$ & DB & $2.0 \%$ & Yes & & & & & \\
\hline NO & 2002-2005 & 1.042 & 28.00 & DB & $15.0 \%$ & DB & $4.0 \%$ & Yes & & & & & \\
\hline
\end{tabular}




\begin{tabular}{|c|c|c|c|c|c|c|c|c|c|c|c|c|c|}
\hline No & 2006-2007 & 1.042 & 28.00 & DB & \begin{tabular}{|l}
$20.0 \%$ \\
\end{tabular} & DB & $4.0 \%$ & Yes & & & & & \\
\hline PL & 1998 & 1.057 & 36.00 & SL & 1 (for R\&D) & SL & $2.5 \%$ & Yes & & & & & \\
\hline PL & 1999 & 1.052 & 34.00 & SL & 1 (for R\&D) & SL & $2.5 \%$ & Yes & & & & & \\
\hline PL & 2000 & 1.043 & 30.00 & SL & 1 (for R\&D) & SL & $2.5 \%$ & Yes & & & & & \\
\hline PL & 2001 & 1.037 & 28.00 & SL & 1 (for R\&D) & $\mathrm{SL}$ & $2.5 \%$ & Yes & & & & & \\
\hline PL & 2002 & 1.038 & 28.00 & SL & $(0.2,0.1,0.1, \ldots)$ & $\mathrm{SL}$ & $2.5 \%$ & Yes & & & & & \\
\hline PL & 2003 & 1.036 & 27.00 & $\mathrm{SL}$ & $(0.3,0.1,0.1, \ldots)$ & $\mathrm{SL}$ & $2.5 \%$ & Yes & & & & & \\
\hline PL & 2004-2005 & 1.023 & 19.00 & SL & $(0.3,0.1,0.1, \ldots)$ & $\mathrm{SL}$ & $2.5 \%$ & Yes & & & & & \\
\hline PL & 2006-2007 & 1.020 & 19.00 & SL & $(0.3,0.1,0.1, \ldots)$ & $\mathrm{SL}$ & $2.5 \%$ & Yes & Tax all. & $\begin{array}{l}\text { "New Technology" } \\
\text { (intang.) assets }\end{array}$ & $50.0 \%$ & & \\
\hline PT & \begin{tabular}{|l|}
$1998-1999$ \\
\end{tabular} & 0.842 & 37.40 & DB & $35.7 \%$ & SL & $5.0 \%$ & No & Tax cr. & Curr. \& Cap. & $8.0 \%$ & $30.0 \%$ & \\
\hline PT & $2000-2001$ & 0.846 & 35.20 & DB & $35.7 \%$ & $\mathrm{SL}$ & $5.0 \%$ & No & Tax cr. & Curr. \& Cap. & $8.0 \%$ & $30.0 \%$ & \\
\hline PT & 2002-2003 & 0.654 & 33.00 & $\mathrm{DB}$ & $35.7 \%$ & $\mathrm{SL}$ & $5.0 \%$ & No & Tax cr. & Curr. \& Cap. & $20.0 \%$ & $50.0 \%$ & \\
\hline PT & 2004-2005 & 0.761 & 27.50 & DB & $35.7 \%$ & SL & $5.0 \%$ & No & Tax cr. & Curr. \& Cap. & $20.0 \%$ & & \\
\hline PT & 2006 & 0.678 & 27.50 & DB & $35.7 \%$ & SL & $5.0 \%$ & No & Tax cr. & Curr. \& Cap. & $20.0 \%$ & $50.0 \%$ & \\
\hline PT & 2007 & 0.683 & 26.50 & DB & $35.7 \%$ & SL & $5.0 \%$ & No & Tax cr. & Curr. \& Cap. & $20.0 \%$ & $50.0 \%$ & \\
\hline SE & 1998-2007 & 1.011 & 28.00 & DB & $30.0 \%$ & SL & $4.0 \%$ & No & & & & & \\
\hline SK & \begin{tabular}{|c|}
$1998-1999$ \\
\end{tabular} & 1.069 & 40.00 & Digi. & 8 years & Digi. & 40 years & Yes & & & & & \\
\hline SK & 2000-2001 & 1.042 & 29.00 & Digi. & 8 years & Digi. & 40 years & Yes & & & & & \\
\hline SK & 2002 & 1.035 & 25.00 & Digi. & 8 years & Digi. & 40 years & Yes & & & & & \\
\hline SK & 2003 & 1.033 & 25.00 & Digi. & 6 years & Digi. & 30 years & Yes & & & & & \\
\hline SK & 2004-2007 & 1.023 & 19.00 & Digi. & 6 years & Digi. & 20 years & Yes & & & & & \\
\hline
\end{tabular}

Source: IBFD (2009a), IBFD (2009b), Devereux et al. (2009), Own research.

Table A-4: Identified applications from matching EPO Bulletin and AMADEUS / by host country of the applicant.

\begin{tabular}{l|clllllllllllllllllll}
\hline Share of EPO applications from & AT & BE & CZ & DE & DK & ES & FI & FR & GB & GR & HU & IE & IT & LU & NL & NO & PL & PT & SE & SK
\end{tabular}

the specific country

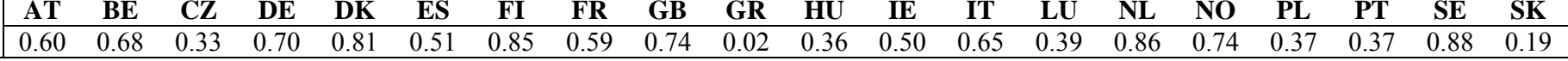

Source: Own calculations.

Table A-5: Identified applications from matching EPO Bulletin and AMADEUS / by year of priority.

\begin{tabular}{|c|c|c|c|c|c|c|c|c|c|c|}
\hline \multirow{3}{*}{$\begin{array}{l}\text { By year of priority } \\
\text { Share of all EPO applications }\end{array}$} & 1998 & 1999 & 2000 & 2001 & 2002 & 2003 & 2004 & 2005 & 2006 & 2007 \\
\hline & 0.34 & 0.34 & 0.33 & 0.34 & 0.34 & 0.33 & 0.32 & 0.31 & 0.32 & 0.23 \\
\hline & 0.71 & 0.71 & 0.71 & 0.72 & 0.72 & 0.71 & 0.69 & 0.68 & 0.68 & 0.66 \\
\hline
\end{tabular}

Share of EPO applications from EEA-

0.7

0.33

0.72

0.72

0.71

0.69

0.68

0.66

Source: Own calculations. 


\section{References}

Acs, Z., L. Anselin and A. Varga (2002), Patents and innovation counts as measures of regional production of new knowledge, Research Policy 31 (7), 1069-1085.

Adams, C. D. and G. M. Godshaw (2002), Intellectual property and transfer pricing, International Tax Review (Supplement - Intellectual Property - April), 74-81.

Atkinson, R. D. (2007), Expanding the R\&D tax credit to drive innovation, competitiveness and prosperity, Journal of Technology Transfer 32 (6), 617-628.

Baghana, R. and P. Mohnen (2009), Effectiveness of R\&D tax incentives in small and large enterprises: analysis of firm data in Québec, Small Business Economics 33 (1), 91107.

Baltagi, B. H. (2001), A Companion to Theoretical Econometrics, Oxford.

Bartik, T. J. (1991), Who benefits from state and local economic development policies?, Kalamazoo.

Bebczuk, R. N. (2002), R\&D expenditures and the role of government, Estudios de Economía (1), 109-121.

Billings, A. B. (2003), Are US tax incentives for corporate R\&D likely to motivate American firms to perform research abroad?, Tax Executive 55 (4), 291-315.

Blasnik, M. (2010), RECLINK: Stata module to probabilistically match records, http://econpapers.repec.org/RePEc:boc:bocode:s456876.

Bloom, N. and R. Griffith (2001), The Internationalisation of UK R\&D, Fiscal Studies 22 (3), 337-355.

Bloom, N., R. Griffith and J. van Reenen (2002), Do R\&D Credits Work? Evidence From A Panel Of Countries 1979-97, Journal of Public Economics 85 (1), 1-31.

Bosch, M., D. Lederman and W. F. Maloney (2005), Patenting and research and development, A global view, World Bank, Policy Research Working Paper Series 3739, Washington D.C.

Buettner, T. and M. Ruf (2007), Tax incentives and the location of FDI: Evidence from a panel of German multinationals, International Tax and Public Finance 14 (2), 151-164.

Cameron, A. C. and P. K. Trivedi (2001), Essentials of Count Data Regression, in: Baltagi, B. Hani, A Companion to Theoretical Econometrics, Oxford, 331-348.

Cameron, A. C. and P. K. Trivedi (2010), Microeconometrics using Stata, College Station.

Cantwell, J. and Piscitello L. (2005), Recent Location of Foreign-owned Research and Development Activities by Large Multinational Corporations in the European Regions: The Role of Spillovers and Externalities, Regional Studies 39 (1), 1-16.

Chamberlain, G. (1984), Panel Data, in: Griliches, Z. and M. D. Intriligator, Handbook of Economcetrics II, Amsterdam, 1247-1318.

Cohen, W. M., R. R. Nelson and J. Walsh (2000), Protecting their Intellectual Assets: Appropriability, Conditions and Why U.S. Manufacturing Firms Patent (or not), NBER Working Paper Series 7552, Cambridge.

Council of the European Union, Council Directive 2003/49/EC of 3 June 2003 on a common system of taxation applicable to interest and royalty payments made between associated companies of different Member States, Official Journal L 157, 49-54.

Crepon, B. and E. Duguet (1997), Research and development, competition and innovation Pseudo-maximum likelyhodd and simulated maximum likelihood methods applied to count data models with heterogeneity, Journal of Econometrics 79 (2), 355-378.

Dischinger, M. and N. Riedel (2010), Corporate taxes and the location of intangible assets within multinational firms, Journal of Public Economics (forthcoming).

Debatin, H., F. Wassermeyer and R. Korn (2009), Doppelbesteuerung, München. 
Defever, F. (2006), Functional fragmentation and the location of multinational firms in the enlarged Europe, Regional Science and Urban Economics 36 (5), 658-677.

Devereux, M. P. and R. Griffith (1999), The taxation of discrete investment choices, Institute for Fiscal Studies Working Paper 98/16 (Revision 2), London.

Devereux, M. P., C. Elschner, D. Endres and C. Spengel (2009), Effective levels of company taxation within an enlarged EU, Project for the EU Commission TAXUD/2008/CC/099, Report October 2009, Mannheim.

Devereux, M. P. (2007), The Impact of Taxation on the Location of Capital, Firms and Profit: a Survey of Empirical Evidence, Oxford University Centre for Business Taxation, Working Paper 0702, Oxford.

Devereux, M. P. and R. Griffith (2003), Evaluating Tax Policy for Location Decisions, International Tax and Public Finance 10 (2), 107-126.

Edler, J., R. Döhrn and M. Rothgang (2003), Internationalisierung industrieller Forschung and grenzüberschreitendes Wissensmanagement, Heidelberg.

Endres, D., A. Oestreicher, W. Scheffler and C. Spengel (2007), The determination of corporate taxable income in the EU member states, Alphen aan den Rijn.

Ernst\&Young (2008), Precision under pressure, Global transfer pricing survey 2007-2008, Nassau.

Expert Group on R\&D Tax Incentives Evaluation (2008), Comparing Practices in R\&D Tax Incentives Evaluation, Final Report for the European Commission, October 31, 2008, Brussels.

Eynatten, W. (2008), European R\&D and IP Tax Regimes, Intertax 36 (11), 502-519.

Eynatten, W. and P. Brauns (2010), Benelux tax competition to attract IP income is on again, International Tax Review (3), March 2010.

Falk, M. (2006), What drives business Research and Development (R\&D) intensity across Organisation for Economic Co-operation and Development (OECD) countries?, Applied Economics 38 (5), 533-547.

Fletcher, R. and S. Cawdron (2006), What you should know about intangibles and UK tax, International Tax Review (12/1), 3-7.

Frick, T. and M. Kronauer (2005), Benefiting from a Swiss-based IP company, International Tax Review (12/1), 32-36.

Ginarte, J. C. and Park W. G. (1997), Determinants of patent rights: A cross-national study, Research Policy 26 (3), 283-301.

Griliches, Z. (1990), Patent statistics as economic indicators: a survey, Journal of Economic

Literature 28 (4), 1661-1707.

Guellec, D. and B. van Pottelsberghe de la Potterie (2003), The Impact of Public R\&D Expenditure on Business R\&D, Economics of Innovation and New Technology 12 (3), $225-243$.

Guimón, J. (2009), Government strategies to attract R\&D-intensive FDI, Journal of Technology Transfer 34 (4), 364-379.

Hall, B. H., Z. Griliches and J. A. Hausman (1986), Patents and R\&D: Is There A Lag, International Economic Review 27 (2), 265-284.

Hall, B. H., J. Mairesse and P. Mohnen (2010), Measuring the Returns to R\&D, Centre interuniversitaire de recherche en analyses des organisations, Scientific Series, 2010s-02, Montréal.

Hall, B. H. and R. Oriani (2006), Does the market value R\&D investment by European firms? Evidence from a panel of manufacturing firms in France, Germany, and Italy, International Journal of Industrial Organization 24 (5), 971-993.

Hall, B. H. and J. van Reenen (2000), How Effective are Fiscal Incentives for R\&D? A Review of the Evidence, Research Policy 29 (4), 467-469. 
Harhoff, D., F. Narin and Vopel K. (1999), Citation Frequency and the Value of Patented Inventions, Review of Economics and Statistics 81 (3), 511-515.

Harhoff, D. and G. Thoma (2009), Inventor Location and the Globalization of R\&D, Conference Advancing the Study of Innovation and Globalization in Organizations (ASIGO) in Nürnberg, Discussion Paper, Nürnberg.

Hausman, J., B. H. Hall and Z. Griliches (1984), Econometric Models for Count Data with an Application to the Patents-R\&D Relationship, Econometrica 52 (4), 909-937.

Henshall, J. (2010), Transfer pricing and intellectual property, http://www.buildingipvalue.com/06KTI/038_041.htm.

Hines, J. R. (1994), No Place Like Home: Tax Incentives and the Location of R\&D by American Multinationals, NBER Working Papers 4574, Washington D.C.

Hollenstein, H. (2008), Characteristics of Foreign R\&D Strategies of Swiss Firms. Implications for Policy, WIFO Working Papers 315, Wien.

Hoogendoorn, M. N. (1996), Accounting and taxation in Europe - A comparative overview, European Accounting Review 5 (1), 783-794.

IBFD (2009a), Corporate Taxation in Europe, Amsterdam.

IBFD (2009b), European tax handbook, Amsterdam.

Jacobs, O. H. (2007), Internationale Unternehmensbesteuerung, München.

Karkinsky, T. and N. Riedel (2009), Corporate Taxation and the Choice of Patent Location Within Multinational Firms, Oxford University Centre for Business Taxation, WP 09/31, November 2009, Oxford.

Keuschnigg, C. (2007), Exports, Foreign Direct Investment and the Costs of Corporate Taxation, CESIFO Working Paper 2114, München.

Kuemmerle, W. (1997), Building Effective R\&D Capabilities Abroad, Harvard Business Review 75 (2), 61-70.

Kumar, N. (1996), Intellectual property protection, market orientation and location of overseas R\&D activities by multinational enterprises, World Development 24 (4), 673-688.

Kumar, N. (2001), Determinants of location of overseas R\&D activity of multinational enterprises: the case of US and Japanese corporations, Research Policy 30 (1), 159-174.

Lall, S. (1979), The international allocation of research activity by US multinationals, Oxford Bulletin of Economics and Statistics 41 (4), 313-331.

Le Bas, C. and C. Sierra (2002), 'Location versus home country advantages' in R\&D activities, Research Policy 31 (4), 589-609.

Lederman, D. and W. F. Maloney (2003), Research and development (R\&D) and development, World Bank Policy Research Working Paper Series 3024, Washington D.C.

Liangqi, L. (1994), Economic determinants of voluntary accounting choices for research and development expenditures in Belgium, European Accounting Review 3 (1), 166-167.

Mansfield, E., D. Teece and A. Romeo (1979), Overseas Research and Development by USBased Firms, Economica 46 (182), 187-196.

Marti, A. and D. Ledergerber (2005), Internationale Steuerplanung mit immateriellen Wirtschaftsgütern, Der Schweizer Treuhänder (3), 187-195.

McFetridge, D. G. and J. P. Warda (1983), Canadian $R$ \& D incentives, their adequacy and impact, Canadian Tax Foundation, Canadian Tax papers 70, Toronto.

Meeker, H. J. (2003), Structuring intellectual property for hi-tech firms, International Tax Review $14(8), 46$.

Mandlak, Y. (1978), On the Pooling of Time Series and Cross Section Data, Econometrica 46 (1), 69-85.

Mutti, J. and H. Grubert (2008), The Effect of Taxes on Royalties and the Migration of Intangible Assets Abroad, Paper prepared for the NBER/CRIW Conference on International Service Flows, Januar 2008, Washington D.C. 
Nárdiz, A. M. (2008), Spanish patent box regime: an attractive location for R\&D, International Tax Review 19 (3), 72-73.

Norton, C. and P. Burns (2006), Transfer pricing for intangible development: cost-sharing alternatives, International Tax Review (12), 47-51.

OECD (2005), Tax Treatment of Business Investments in Intellectual Assets: An International Comparison, Working Party on Innovation and Technology Policy, Version 30.11.2005, Paris.

OECD (2009), Transfer Pricing Guidelines for Multinational Enterprises and Tax Administrations, Paris.

Park, W. G. (2008), International patent protection: 1960-2005, Research Policy 37 (4), $761-$ 766.

Parsons, M. and N. Phillips (September 2007), An Evaluation of the Federal Tax Credit for Scientific Research and Experimental Development, Department of Finance Canada, Working Paper 2007-08, Ottawa.

Patel, P. and M. Vega (1999), Patterns of internationalisation of corporate technology: location vs. home country advantages, Research Policy 28 (2-3), 145-155.

Pavitt, K. L.R. (1985), Patents statistics as indicators of innovative activities: possibilities and problems, Scientometrics 7 (1-), 77-99.

Phillips, J. M. and E. P. Goss (1995), The Effect of State and Local Taxes on Economic Development: A Meta-Analysis, Southern Economic Journal 62 (2), 320-333.

Quick, P. D. and T. L. Day (2006), Management of IP: Intercompany Transfers, Offshore Planning and Recent Developments Regarding Cost-Sharing, The Licensing Journal (1), 14-21.

Russo, R., C. Finnerty, P. Merks and M. Petriccione (2007), Fundamentals of international tax planning, Amsterdam.

Sanyal, P. (2004), Intellectual property rights protection and location of R\&D by multinational enterprises, Journal of Intellectual Capital 5 (1), 59-76.

Scherer, F. M. (1983), The propensity to patent, International Journal of Industrial Organization $1(1), 107-128$.

Scheunemann, M. P. and A. Dennisen (2010), Steuerliche Strukturierung von Forschung and Entwicklung im internationalen Konzern, Der Betrieb (8), 408-413.

Schuch, J. and C. Wehinger (2005), Steuerliche Forschungsförderung bei Auslandsforschung, ecolex, 192-196.

Sougiannis, T. (1994), The Accounting Based Valuation of Corporate R\&D, The Accounting Review 69 (1), 44-68.

Stifterverband für die Deutsche Wissenschaft (2009), FuE-Datenreport 2009, Essen.

Swanson, Z. L. and R. Singer (2002), Are Investor Reactions to R\&D Influenced by the Corporate Headquarter's Location?, Review of Quantitative Finance and Accounting 18 (1), 5-19.

Taieb, S. (2008), Reforming the tax regime for patents, International Tax Review 18 (1), 1414.

Thoma, G., S. Torrisi, A. Gambardella, D. Guellec, B. H. Hall and D. Harhoff (2010), Harmonizing and Combining Large Datasets - An Application to Firm-Level Patent and Accounting Data, NBER Working Papers No. 15851, Cambridge.

Verlinden, I. and A. Smits (2009), Mastering the Intellectual Property Life Cycle, SintStevens-Woluwe.

Vögele, A., T. Borstell, G. Engler and H. Kotschenreuther (2004), Handbuch der Verrechnungspreise, München.

Wakelin, K. (1998), The role of innovation in bilateral OECD trade performance, Applied Economics 30 (10), 1335-1346. 
Warda, J. (2001), Measuring the Value of R\&D Tax Treatment in OECD Countries, OECD STI Review (27).

Warda, J. P. (1990), International Tax Competitiveness of Canadian R\&D Tax Incentives: an Update, The Conference Board of Canada, Ottawa.

Wilson, D. J. (2009), Beggar Thy Neighbor? The In-State, Out-of-State, and Aggregate Effects of R\&D Tax Credits, The Review of Economics and Statistics 91 (2), 431-436.

Yang, Q. and C. Jiang (2007), Location advantages and subsidiaries' R\&D activities in emerging economies: Exploring the effect of employee mobility, Asia Pacific Journal of Management 24 (3), 341-358.

Zuniga, M. P. and D. Guellec (2009), Who Licenses out Patents and Why?, OECD Science, Technology and Industry Working Papers 2009/5, Paris. 